\title{
Detection of the HIV-1 accessory proteins Nef and Vpu by flow cytometry represents a new tool to study their functional interplay within a single infected CD4+ $T$ cell
}

Jérémie Prévost ${ }^{1,2, *}$, Jonathan Richard ${ }^{1,2, *}$, Romain Gasser $^{1,2}$, Halima Medjahed ${ }^{1}$, Frank Kirchhoff $^{3}$, Beatrice H. Hahn ${ }^{4}$, John C. Kappes ${ }^{5}$, Christina Ochsenbauer ${ }^{5}$, Ralf Duerr ${ }^{6}$, Andrés Finzi $1^{1,2,7, \#}$

${ }^{1}$ Centre de Recherche du CHUM, Montreal, Quebec, Canada

${ }^{2}$ Département de Microbiologie, Infectiologie et Immunologie, Université de Montréal, Montreal, Quebec, Canada

${ }^{3}$ Institute of Molecular Virology, Ulm University Medical Center, Ulm, Germany.

${ }^{4}$ Departments of Medicine and Microbiology, Perelman School of Medicine, University of Pennsylvania, Philadelphia, PA, USA

${ }^{5}$ Department of Medicine, University of Alabama at Birmingham, Birmingham, AL, USA

${ }^{6}$ Department of Microbiology, New York University School of Medicine, New York, NY, USA

${ }^{7}$ Department of Microbiology and Immunology, McGill University, Montreal, Quebec, Canada

*Contributed equally

${ }^{\#}$ Corresponding author:

Andrés Finzi

Centre de recherche du CHUM (CRCHUM)

900 St-Denis street, Tour Viger, R09.420

Montréal, Québec, H2X 0A9, Canada

andres.finzi@,umontreal.ca

Phone: 514-890-8000 ext: 35264

Fax: 514-412-7936

Running Title: Nef and Vpu expression dictates ADCC responses

Key Words: HIV-1, Env, Nef, Vpu, CD4, BST-2, ADCC, LucR.T2A, non-neutralizing antibodies, CD4-bound conformation 


\section{ABSTRACT}

37 The HIV-1 Nef and Vpu accessory proteins are known to protect infected cells from antibodydependent cellular cytotoxicity (ADCC) responses by limiting exposure of CD4-induced (CD4i)

39 envelope (Env) epitopes at the cell surface. Although both proteins target the host receptor CD4 for degradation, the extent of their functional redundancy is unknown. Here, we developed an

41 intracellular staining technique that permits the intracellular detection of both Nef and Vpu in

42 primary CD4+ $\mathrm{T}$ cells by flow cytometry. Using this method, we show that the combined

43 expression of Nef and Vpu predicts the susceptibility of HIV-1-infected primary CD4+ T cells to

44 ADCC by HIV+ plasma. We also show that Vpu cannot compensate for the absence of Nef, thus

45 providing an explanation for why some infectious molecular clones that carry a LucR reporter 46 gene upstream of Nef render infected cells more susceptible to ADCC responses. Our method

47 thus represents a new tool to dissect the biological activity of Nef and Vpu in the context of other 48 host and viral proteins within single infected CD4+ T cells.

\section{IMPORTANCE}

51 HIV-1 Nef and Vpu exert several biological functions that are important for viral immune

52 evasion, release and replication. Here, we developed a new method allowing simultaneous

53 detection of these accessory proteins in their native form together with some of their cellular

54 substrates. This allowed us to show that Vpu cannot compensate the lack of a functional Nef, 55 which has implication for studies that use Nef-defective viruses to study ADCC responses. 


\section{INTRODUCTION}

58 The human immunodeficiency virus type 1 (HIV-1) genome encodes four accessory proteins

59 (Vif, Vpr, Vpu and Nef), which are dispensable for viral replication in vitro but required

60 for efficient replication, restriction factors counteraction and immune evasion in vivo (1-

61 7). Among them, Nef and Vpu are well known for their role in subverting the host cell

62 protein trafficking machinery $(8,9)$.

63

$64 \mathrm{HIV}-1 \mathrm{Nef}$ is a small cytoplasmic protein of $27 \mathrm{kDa}$ produced from early viral transcripts (10),

65 which requires a myristoyl group on its N-terminus to traffic to intracellular and plasma membranes (11). Nef harbors a highly conserved dileucine motif in its C-terminal flexible loop

67 that is responsible for the interaction with clathrin adaptors protein complexes (AP-1, AP-2 and AP-3) (12). Among these, interaction with AP-2 is required to downregulate the CD4 receptor

69 from the surface of infected cells $(13,14)$ and target it for degradation in lysosomal compartments $(15,16)$.

71

$72 \mathrm{HIV}-1 \mathrm{Vpu}$ is a small type-I transmembrane protein of $16 \mathrm{kDa}$ produced late in the viral 73 replication cycle $(17,18)$ and contains a short luminal N-terminal peptide followed by a single 74 helical transmembrane domain and a C-terminal cytoplasmic domain (19-21). The cytoplasmic 75 domain is comprised of two $\alpha$-helices linked by a flexible loop known for its interaction with the $76 \mathrm{SCF}^{\beta T R C P}$ E3 ubiquitin ligase complex via a conserved phosphoserine motif $\left(\operatorname{DS}^{\mathrm{P}} \mathrm{GNES}^{\mathrm{P}}\right)(22$, 77 23). Vpu mainly localizes within intracellular compartments, notably the endoplasmic reticulum 78 (ER) and the trans-Golgi network (TGN) (24-26). Like Nef, Vpu also induces degradation of 79 newly synthesized CD4 by directing it through an ER-associated pathway (ERAD) for further 
80 proteasomal degradation $(22,27-29)$. In addition, Vpu sequesters the restriction factor BST-2 in

81 the TGN using its transmembrane domain, thereby increasing the release of progeny virions (30-

$8233)$.

$84 \mathrm{CD} 4$ downregulation by Nef and Vpu was previously reported to be critical for efficient viral 85 replication in $\mathrm{T}$ cells by enhancing virion release and infectivity, and by preventing superinfection (34-39). CD4 downregulation is critical for immune evasion since the anti-Env

87 antibody $(\mathrm{Ab})$ response is dominated by non-neutralizing antibodies (nnAbs) that target Env in

88 its "open" CD4-bound conformation (40-42). The interaction between CD4 and Env at the

89 surface of HIV-1-infected cells has been shown to promote nnAbs binding to Env, leading to the

90 elimination of infected cells through Fc-mediated effector functions, including antibody-

91 dependant cellular cytotoxicity (ADCC) (41, 43). Nef and Vpu limit the presence of Env-CD4

92 complexes at the cell surface and thus protect infected cells against ADCC $(41,43,44)$.

94 In previous studies, Nef and Vpu expression was mostly examined in transfected cell lines, 95 frequently using tagged proteins $(30,31,45,46)$ or by performing Western blots and 96 immunofluorescence microscopy in infected primary cells (47-52). However, both proteins are

97 small, intracellularly located and present in low amounts, rendering their detection difficult. To 98 facilitate their analysis in primary CD4+ T cells, we developed an intracellular staining technique 99 to detect Nef and Vpu expression by flow cytometry, which allows the simultaneous detection of 100 these proteins together with host and viral proteins within a single infected cell. Using this 101 method, we show that Nef and Vpu expression predicts the susceptibility of HIV-1-infected 102 primary $\mathrm{CD} 4+\mathrm{T}$ cells to $\mathrm{ADCC}$ by $\mathrm{HIV}+$ plasma. We also explain why decreased Nef 

responses.

\section{RESULTS}

\section{Intracellular detection of Nef and Vpu in HIV-1-infected primary CD4+ T cells.}

108 To facilitate detection of intracellular Nef, we obtained a polyclonal Nef antiserum through the 109 NIH AIDS Reagent Program, which was generated by immunization of rabbits with a 110 recombinant clade B Nef consensus protein produced in E. coli (53). In previous studies, this antibody detected native Nef proteins by Western blot and immunofluorescence microscopy in

112 both transfected and infected cells $(47,54-56)$. Given the scarcity of anti-Vpu antibodies, we

113 immunized rabbits with a peptide corresponding to the clade B Vpu C-terminal region (residues

114 69-81). A similar approach was previously used to generate a polyclonal antibody capable of 115 detecting Vpu by Western blot and immunofluorescence microscopy $(24,57)$.

117 We first evaluated the ability of both Nef and Vpu antisera to recognize their cognate antigen 118 using HEK 293 T cells transfected with plasmids expressing the Nef or Vpu proteins from the 119 transmitted/founder (T/F) virus $\mathrm{CH} 058(58,59)$. Forty-eight hours post-transfection, cells were 120 permeabilized and stained with the antisera, followed by detection with a fluorescently-labelled 121 anti-rabbit secondary antibody. As expected, the Nef antiserum recognized only Nef transfected 122 cells, while the Vpu antiserum recognized only Vpu transfected cells (Fig. 1A-C). To evaluate 123 whether our method detected Nef and Vpu when expressed in a biologically relevant culture 124 system, we infected primary CD4+ T cells with $\mathrm{CH} 058$ infectious molecular clones (IMC) 125 encoding Nef, and/or Vpu proteins. While wildtype (WT)-infected cells were efficiently 
recognized by both Nef and Vpu antisera, abrogation of Nef (Fig 1D-E) or Vpu (Fig. 1F-G) expression prevented the recognition of productively-infected cells as identified by Gag protein intracellular staining (p24+). Of note, mock-infected or uninfected bystander cells (p24-) where not detected by either antiserum, further confirming their specificity (Fig 1D-G).

We next examined the antiserum binding to Nef and Vpu proteins from different HIV-1 clades and groups as well as from closely related simian immunodeficiency viruses (SIV). Primary CD4+ $\mathrm{T}$ cells were infected with a panel of HIV-1 IMCs representing clades B, C, A1 and CRF01_AE. As expected, both Nef and Vpu antisera recognized their respective antigen in cells infected with clade B viruses since both were raised against clade B immunogens (Fig. 1H-I). The anti-Nef polyclonal antibody was also able to recognize Nef proteins from group M clades C, A1 and CRF01_AE as well as the Nef from a group O isolate. This recognition extended even to the Nef protein of a related SIVcpzPts strain (isolate TAN2) but not to chimeric simian-human immunodeficiency viruses (SHIV) which express a SIVmac Nef (Fig. 1H). The Vpu antiserum was less cross-reactive and failed to detect Vpu from clade $\mathrm{C}$ viruses (Fig. 1I). These findings confirmed the specificity and cross-reactivity of the intracellular detection of Nef and Vpu using infected primary CD4+ T cells.

\section{Measuring CD4 and BST-2 downregulation in infected primary CD4+ $T$ cells with or} without Nef and Vpu expression.

The efficient detection of Nef and Vpu at the single cell level by flow cytometry allowed us to combine this approach with the quantification of CD4 and BST-2 expression levels on the cell surface. Productively-infected cells (p24+) expressing both Nef and Vpu had little detectable 
CD4 and BST-2 compared to uninfected cells (Fig. 2A). In contrast, cells infected with Vpu or

Nef mutant viruses differed in the extent of CD4 and BST-2 downregulation (Fig. 2A).

152 Vpu targets CD4 and BST-2 by different mechanisms. First, Vpu interacts with multiple transmembrane proteins, including BST-2, through its transmembrane domain (TMD), which

154 sequesters these proteins in perinuclear compartments (32, 33, 60-63). Second, Vpu downregulates CD4 by interaction of its cytoplasmic domain with the cytoplasmic tail of CD4 (64-69). Consistent with these different interaction modes, Vpu-mediated CD4 and BST-2 degradation involves independent pathways (proteasomal and lysosomal degradation, respectively), both of which depend on polyubiquitination by the $\mathrm{SCF}^{\beta \mathrm{TRCP}} \mathrm{E} 3$ ubiquitin ligase complex, recruited by Vpu using its highly conserved phosphoserine motif $(22,26,70,71)$. To examine whether we could measure the expression and activity of Vpu mutants by flow cytometry, we introduced mutations at critical residues of the Vpu TMD (A14L/A18L) or its phosphoserine motif (S52A/S56A). CH058 IMCs coding for wildtype or mutated Vpu proteins were used to infect primary CD4+ $\mathrm{T}$ cells. While the TMD mutations did not affect Vpu expression, the phosphoserine mutations led to a significant accumulation of intracellular Vpu proteins (Fig. 2B), most likely because $\mathrm{Vpu}$ is degraded together with its target protein as a 166 ubiquitinated complex $(24,72,73)$. Despite a higher expression, the Vpu phosphoserine mutant 167 was unable to downregulate CD4 and marginally diminished in its capacity to antagonize BST-2 168 (Fig 2C-F). This is consistent with studies demonstrating that the recruitment of the SCF ${ }^{\beta T R C P}$ E3 ubiquitin ligase complex and the degradation of BST-2 by Vpu is dissociable from its capacity to antagonize the restriction factor $(32,71,74-76)$. In contrast, the Vpu TMD mutations did not

171 affect Vpu's ability to target CD4 but completely abrogated its capacity to downregulate BST-2 
172 (Fig 2C-F). Together, these results emphasize the need of measuring Nef and Vpu expression 173 when studying their biological functions.

175 Nef and Vpu expression inversely correlates with ADCC responses.

$176 \mathrm{CD} 4$ downregulation by Nef and Vpu, together with Vpu-mediated BST-2 antagonism were

177 found to be critical factors preventing the exposure of vulnerable CD4-induced Env epitopes, 178 thus protecting HIV-1-infected cells from $\operatorname{ADCC}(41,43,44,77-80)$. To investigate the link 179 between Nef and Vpu expression and HIV-1-infected cells immune evasion, we infected 180 activated primary CD4+ T cells from five HIV-negative individuals with two clade B IMCs, $181 \mathrm{CH} 058 \mathrm{~T} / \mathrm{F}$ and JR-FL, encoding functional or defective nef and $v p u$ genes. Focusing on the 182 productively-infected cells (p24+), we performed a comprehensive characterization of the 183 patterns of viral protein expression including cell-surface Env (detected with the conformation184 independent $\mathrm{Ab}$ 2G12), intracellular Nef and Vpu in combination with cell-surface levels of CD4 185 and BST-2. We also measured the specific recognition and elimination of infected cells by ADCC using the CD4-induced (CD4i) A32 monoclonal Ab (mAb). This antibody binds the 187 cluster A region of the gp120 which is occluded in the "closed" trimer and therefore can only 188 bind Env in the "open" CD4-bound conformation. We also tested 25 different plasma samples 189 from chronically HIV-1-infected individuals. As expected, Nef was only expressed by WT and 190 Vpu- constructs, while Vpu was only expressed by WT and Nef- constructs (Fig. 3A). Consistent 191 with previous reports $(43,77,78)$, deletion of Nef strongly impaired CD4 downregulation by 192 both viruses but did not affect Env or BST-2 cell-surface levels. Vpu deletion mitigated CD4 193 downregulation to a lesser extent than Nef and abrogated BST-2 downmodulation, resulting in an 194 overall increase in the amount of cell-surface Env (Fig. 3B). We noticed lower levels of the JR- 
FL Vpu protein compared to $\mathrm{CH} 058 \mathrm{Vpu}$, which was linked to a less effective Vpu-mediated responses mediated by A32 and HIV+ plasma (Fig. 3C-D). In contrast, abrogation of Nef or Vpu expression resulted in increased recognition and susceptibility of infected cells to ADCC mediated by nnAbs (Fig. 3C-D). We performed correlation analyses to measure the level of association between the different cellular, virological and immunological variables (Fig 3E-F). We found that both Nef and Vpu established a large network of inverse correlations with cellular and immunological factors. Interestingly, Env levels hardly contributed to the network and were poorly associated with the immunological outcome, thus indicating that the overall amount of

205 Env present at the surface does not dictate ADCC responses mediated by CD4i Abs or HIV+ responses mediated by nnAbs correlated strongly with CD4 and Nef levels (Fig. 3E-F). Overall, Nef and Vpu expression inversely correlates with the susceptibility of HIV-1-infected cells to ADCC mediated by CD4i Abs and HIV+ plasma.

213 Infectious molecular clones encoding for the Renilla luciferase (LucR) reporter gene upstream of

214 the nef sequence, and a T2A ribosome-skipping peptide to drive Nef expression are widely 215 employed to quantify anti-HIV-1 ADCC responses (81-92). Despite evidence that Nef-mediated 216 CD4 downregulation is impaired when using these IMCs $(54,79)$, a series of recent studies have hypothesized that $\mathrm{Vpu}$ can compensate for the absence of Nef expression and completely 
downregulate CD4 on its own (93-97). To evaluate this hypothesis, we used our intracellular staining to measure Nef and Vpu expression levels and study their impact on ADCC responses mediated by nnAbs against cells infected with IMC-LucR.T2A constructs. Primary CD4+ T cells were infected with NL4.3-based IMCs that do (Env-IMC-LucR.T2A) or do not encode (EnvIMC) a LucR.T2A cassette. These IMCs express the Env ectodomain from two clade B viruses, CH058 T/F and YU-2. Consistent with the lack of Nef detection by Western blot $(54,79)$, insertion of the LucR.T2A cassette also impaired the detection of Nef by flow cytometry, while Vpu expression remained unchanged (Fig. 4A-B). However, we noted an accumulation of cellsurface CD4 for Env-IMC-LucR.T2A compared to nef-intact constructs ( 20-fold higher) (Fig. 4C), which resulted in a significantly increased recognition and susceptibility of infected cells to ADCC responses mediated by $\mathrm{A} 32 \mathrm{mAb}$ and $\mathrm{HIV}+$ plasma (Fig. 4D-E). Of note, both the binding and the ADCC responses mediated by nnAbs were strongly associated with CD4 levels and inversely correlated with Nef expression (Fig 4F-G). In contrast, these variables poorly correlated with Vpu expression. Based on these data, it seems clear that Vpu expression alone is not sufficient to prevent ADCC-mediated killing of infected cells and that HIV-1 requires both Nef and Vpu for efficient humoral response evasion.

\section{Nef, Vpu and CD4 levels predict ADCC responses mediated by HIV+ plasma.}

We next used univariate multiple linear regression (MLR) analysis to evaluate the capacity of different variables to predict ADCC responses mediated by HIV+ plasma. This model is based on the hypothesis that a linear relationship exists between the dependant variable quantified empirically and the independent variables that serve as predictive variables. In our model, the dependant variable is the ADCC responses mediated by plasma from HIV+ donors (ADCC 
241 HIV+ plasma) and the independent variables are the cellular, virological and immunological 242 factors measured on infected cells. To run the MLR model, we combined data obtained with the 243 different viral constructs (Fig. 3 \& 4) and plotted the mean ADCC obtained with 25 HIV+ 244 plasma against a single virus on the $\mathrm{X}$ axis and the associated predicted ADCC value based on 245 one or more independent variables on the $\mathrm{Y}$ axis. When looking at cellular factors, we noticed 246 that only CD4 accurately predicts ADCC responses mediated by HIV+ plasma, independent of 247 the viral strain (Fig. 5A). Even though BST-2 displayed a strong correlation with ADCC 248 responses (Fig 3E), it was not predictive. When focusing on virological variables, we observed that Nef is the only significant ADCC predictive variable, albeit not as good as CD4 (Fig. 5A-B). However, combinations of Nef with Vpu or Env increased its predictive scores, reaching similar 251 levels as CD4 when combined with Vpu (Fig. 5B). Of note, the strength of the prediction was not 252 further improved when combining all three virological variables altogether. As for 253 immunological variables, their capacity to predict ADCC by HIV+ plasma was found to be 254 equivalent or even higher than for cellular and virological factors (Fig. 5C). Indeed, the binding 255 of HIV+ plasma predicted ADCC values with a similar score as CD4 or Nef and Vpu combined, 256 while the binding of A32 predicted ADCC by HIV+ plasma even better (Fig. 5A-C). This could 257 be explained by the fact that A32-like Abs present in plasma from infected individuals are from 258 the main class of Abs (anti-cluster A Abs) mediating ADCC responses against infected cells (41, $25980,81,91,98)$. In line with this interpretation, ADCC mediated by A32 was found to have a 260 near-perfect predictive ability, suggesting that factors, other than antibody binding, are 261 presumably needed to fully explain the ADCC phenotypes observed (Fig. 5C). 


\section{DISCUSSION}

265 Unlike simple retroviruses, HIV-1 and related SIVs encode multiple accessory proteins that

266 promote viral replication and immune evasion (99). Among them, Nef and Vpu modulate the

267 expression, trafficking, localization and function of several host cell surface proteins, including

268 the viral receptor CD4, restriction factors and homing receptors $(28,30,31,62,69,100-104)$.

269 They also modulate a wide range of immunoreceptors to evade immune responses mediated by

270 CD8+ T, NK and NKT cells (105-113). Most of these host cell proteins are naturally expressed

271 on primary CD4+ T cells, the preferential target of HIV-1. The detection of Nef and Vpu has

272 previously been done in transfected cells $(30,31,46,48,49,114)$, which results in the

273 overexpression of the viral proteins when compared to infected primary CD4+ $\mathrm{T}$ cells.

274 Moreover, tagged viral proteins are frequently used to facilitate their detection $(30,31,46,48$,

275 49, 114). Protein overexpression and/or tag insertion, have the potential to impact the trafficking

276 and functions of these accessory proteins. To study Nef and Vpu's biological activities in a

277 physiologically relevant system, we developed an intracellular staining method to detect native

278 Nef and Vpu proteins in HIV-1-infected primary CD4+ T cells by flow cytometry. Using Nef

279 and Vpu antisera, we detected both viral proteins with high specificity in cells productively

280 infected (p24+) with multiple IMCs. The Nef antiserum was cross-reactive, detecting Nef from

281 group $\mathrm{M}$ (clade B, C, A1 and CRF01_AE), from a group O isolate and from a closely related

282 SIVcpz strain. In contrast, the Vpu antiserum recognized only clade B Vpu proteins, consistent

283 with the fact that we used a peptide from the C-terminal region of clade B Vpu. This region is

284 highly variable among group $\mathrm{M}$ viruses (115). More conserved regions of Vpu map to the

285 transmembrane domain of the protein and the $\beta$ TRCP binding site $(116,117)$. However, these

286 regions are either buried into the plasma membrane or occluded by cellular partners, and thus are 
287

288

289

290

291

292

293

294

295

296

297

298

299

300

301

302

303

304

305

306

307

308

309

not readily accessible for antibody recognition. While the generation of a broad Vpu antiserum is challenging, it may be possible to generate clade-specific Vpu antisera by immunization using peptides corresponding to the C-terminal region specific for a given clade.

Nef and Vpu intracellular detection by flow cytometry represents an excellent tool to study their biological activities in HIV-1-infected primary CD4+ $\mathrm{T}$ cells. This method allows for the detection of cell-surface substrates or antibody recognition of surface Env and the concomitant detection of Nef and Vpu expression within a single infected cell (Fig. 2A). Infected CD4+ T cells represent the most relevant system to study the complex interplay between these two accessory proteins and the wide range of host cell factors naturally expressed by $\mathrm{T}$ cells. Recent findings revealed that modulation of BST-2 levels by type I IFN impacts the capacity of Vpu to downregulate NTB-A, PVR, CD62L and Tim-3, thus reducing its polyfunctionality $(63,69)$. Nef and Vpu also display overlapping functions, as they share the capacity to downregulate several cell-surface proteins, including CD4, PVR, CD62L and CD28 (8, 56, 62, 110, 118). The expression levels of one viral protein could therefore modulate the biological activities of the other, making it essential to study their functions in a context where both viral proteins are expressed simultaneously at physiological levels. Thus, our intracellular staining measuring Nef/Vpu expression and functionality in HIV-1-infected cells represents a new approach to better characterize their functional interplay.

Increasing evidence points towards Env conformation on the surface of infected cells as a critical parameter of ADCC susceptibility to HIV+ plasma (41, 119-121). Non-neutralizing antibodies in the plasma from HIV-1-infected individuals target epitopes that are only exposed when Env 
310 interacts with cell-surface CD4, thus adopting the "open” CD4-bound conformation (41, 43). Nef

311 and Vpu contribute to protect HIV-1-infected cells from ADCC by limiting Env-CD4 interaction

312 via CD4 downregulation and BST-2 antagonism (41, 43, 44, 77, 78). Here we confirm and

313 extend previous observations by showing that Nef and Vpu expression predicts the susceptibility

314 of HIV-1-infected primary CD4+ T cells to ADCC responses. In agreement with recent studies

$315(44,79)$, we found that CD4 accurately predicted the susceptibility of infected cells to ADCC

316 (Fig. 5). Given its enhanced capacity to downregulate CD4 compared to Env or Vpu (34, 41, 43,

317 118), Nef represents the main viral factor influencing ADCC responses mediated by CD4-

318 induced ligands (Fig. 5B). On the contrary, BST-2 and Env expression, alone or in combination,

319 were unable to accurately predict the susceptibility of infected cells to ADCC. These results are

320 consistent with previous reports suggesting that Env conformation rather than overall cell-

321 surface Env levels, drives ADCC responses mediated by HIV+ plasma $(41,43,120,121)$. This is

322 also in agreement with recent work showing that BST-2 upregulation by type I IFN enhances

323 cell-surface Env levels without increasing the susceptibility of infected cells to ADCC mediated

324 by HIV+ plasma, unless CD4-mimetics are used to "open-up" Env and stabilize the CD4-bound

325 conformation (122).

326

327 A series of recent studies using LucR.T2A IMCs have hypothesized that Vpu can compensate for

328 the absence of Nef expression by fully downregulating cell-surface CD4 (93-97). Our results

329 show that this is not the case. Consistent with its role in targeting CD4 already present at the

330 plasma membrane, the impact of Nef on CD4 downmodulation is more prominent (Fig. 2 \& 3)

$331(34,41,43,118)$. In its absence, Vpu was unable to fully downregulate CD4, thus sensitizing

332 infected cells to ADCC responses. These results highlight the importance of selecting full-length 
unmutated IMCs with proper Nef and Vpu expression to generate biologically relevant ADCC measurements. For example, a recent manuscript recently reported no differences in ADCC susceptibility between cells infected with clade B, clade C or CRF01_AE IMCs (123) while previous studies have shown otherwise $(120,124)$. In this article $(123)$, the authors use functionally Nef defective LucR.T2A IMCs, which results in incomplete CD4 downregulation and therefore exposure of Env in its CD4-bound conformation at the cell surface (Fig. 4) (79). Thus, it is not surprising that the usage of Nef defective viruses skew ADCC responses in favor of nnAbs and mitigate the intrinsic differences that exists between Env from different clades. Fortunately, several alternatives to the use of LucR.T2A IMCs are available to measure ADCC against productively-infected cells (125), including the Infected Cell Elimination (ICE) assay, which measures the loss of productively-infected cells (p24+) by flow cytometry and allows the utilization of unmodified IMCs. Utilization of an NK cells resistant T cell line expressing a Tatdriven luciferase reporter gene (CEM.NKr-CCR5-sLTR-Luc) as target cells also represents an option (126). Finally, luciferase reporter IMCs (referred to as LucR.6ATRi IMCs) expressing similar levels of Nef than those obtained with unmodified IMC are also available. These IMCs utilize a modified encephalomyocarditis virus (EMCV) internal ribosome entry site (IRES) element in lieu of T2A $(54,79)$. Thus, LucR.6ATRi reporter viruses represent a biologically relevant alternative to LucR.T2A IMCs when measuring ADCC mediated by nnAbs and plasma collected from infected or vaccinated individuals.

\section{ACKNOWLEDGMENTS}

The authors thank the CRCHUM BSL3 and Flow Cytometry Platforms for technical assistance, Mario Legault from the FRQS AIDS and Infectious Diseases network for cohort coordination 
and clinical samples. We thank the following collaborators for kindly providing some infectious molecular clones: Dennis Burton (The Scripps Research Institute) for JR-FL, Malcom A. Martin (NIAID) for SHIV AD8-EO, George M. Shaw (UPenn) for SHIV.AE.40100 and Sodsai

359 Tovanabutra (US MHRP) for the HIV-1 wr27, HIV-1 $703357, \mathrm{HIV}-1_{40061}, \mathrm{HIV}-1_{\mathrm{CM} 235}$ and HIV-

3601851891 IMCs. We thank MédiMabs for their scientific and technical support during the

361 development of the $\mathrm{Vpu}$ antiserum. This study was supported by grants from the National 362 Institutes of Health to A.F., C.O. and J.C.K. (R01 AI148379), to A.F. (R01 AI129769 and R01 363 AI150322) and to BHH (R01 AI162646 and UM1 AI164570). This work was also partially 364 supported by 1UM1AI164562-01, co-funded by National Heart, Lung and Blood Institute, 365 National Institute of Diabetes and Digestive and Kidney Diseases, National Institute of 366 Neurological Disorders and Stroke, National Institute on Drug Abuse and the National Institute 367 of Allergy and Infectious Diseases, a CIHR foundation grant \#352417, a CIHR Team grant 368 \#422148 and a Canada Foundation for Innovation grant \#41027 to A.F. A.F. is the recipient of a 369 Canada Research Chair on Retroviral Entry \#RCHS0235 950-232424. F.K. is supported by the 370 Deutsche Forschungsgemeinschaft (CRC 1279 and SPP 1923). J.P. is the recipient of a CIHR 371 doctoral fellowship. The funders had no role in study design, data collection and analysis, 372 decision to publish, or preparation of the manuscript.

\section{AUTHOR CONTRIBUTIONS}

375 J.P. J.R. and A.F. conceived the study. J.P., J.R., and A.F. designed experimental approaches. 376 J.P., J.R., R.G. R.D. and A.F. performed, analyzed, and interpreted the experiments. H.M., F.K., 377 B.H.H., J.C.K. and C.O. supplied novel/unique reagents. J.P., J.R., BHH, and A.F. wrote the 378 paper. All authors have read, edited, and approved the final manuscript. 
CONFLICT OF INTEREST

381 The authors declare no competing interests.

382

\section{DATA AVAILABILITY}

Data and reagents are available upon request.

\section{METHODS}

\section{Ethics Statement}

390 Written informed consent was obtained from all study participants [the Montreal Primary HIV 391 Infection Cohort $(127,128)$ and the Canadian Cohort of HIV Infected Slow Progressors (129392 131), and research adhered to the ethical guidelines of CRCHUM and was reviewed and 393 approved by the CRCHUM institutional review board (ethics committee, approval number CE $394 \quad 16.164$ - CA). Research adhered to the standards indicated by the Declaration of Helsinki. All 395 participants were adult and provided informed written consent prior to enrolment in accordance 396 with Institutional Review Board approval.

\section{Cell lines and isolation of primary cells}

399 HEK293T human embryonic kidney cells (obtained from ATCC) were grown as previously 400 described (132). Primary human PBMCs and CD4+ T cells were isolated, activated and cultured 401 as previously described (43). Briefly, PBMCs were obtained by leukapheresis from HIV- 
402

403

404

405

406

407

408

409

410

411

412

413

414

415

416

417

418

419

420

421

422

423

424

negative individuals (4 males and 1 female) and CD4+ T lymphocytes were purified from resting

PBMCs by negative selection using immunomagnetic beads per the manufacturer's instructions

(StemCell Technologies, Vancouver, BC) and were activated with phytohemagglutinin-L (10

$\mu \mathrm{g} / \mathrm{mL}$ ) for 48 hours and then maintained in RPMI 1640 complete medium supplemented with rIL-2 (100 U/mL).

\section{Plasmids and proviral constructs}

The vesicular stomatitis virus G (VSV-G)-encoding plasmid was previously described (133).

Transmitted/Founder (T/F) and chronic infectious molecular clones (IMCs) of patients CH040,

CH058, CH077, CH131, CH141, CH167, CH185, CH198, CH236, CH269, CH293, CH440, CH470, CH505, CH534, CH850, CM235, MCST, REJO, RHGA, RHPA, STCO, SUMA, TRJO, WARO, WITO, WR27, 40061, 703357 and 851891 were inferred, constructed, and biologically characterized as previously described (120, 134-143). The IMCs encoding for HIV-1 reference strains AD8, JR-FL, JR-CSF, NL4-3, YU-2 were described elsewhere (144-149). HIV-1 group O (RBF206), SIVcpz (TAN2) and chimeric SIVmac/HIV-1 IMC constructs (SHIV AD8-EO and SHIV.AE.40100) were generated as previously published (150-153). CH058 IMCs defective for Vpu and/or Nef expression were previously described (58). To generate a nef-defective JR-FL IMC, a frameshift mutation was introduced at the unique XhoI restriction site within the nef gene, resulting in a premature stop codon at position 47. To generate $v p u$-defective JR-FL IMCs, two stop-codons were introduced directly after the start-codon of $v p u$ using the QuikChange II XL site-directed mutagenesis protocol (Agilent Technologies, Santa Clara, CA). The presence of the desired mutations was determined by automated DNA sequencing. Proviral constructs, collectively referred as Env-IMCs, comprising an HIV-1 NL4.3-based isogenic backbone 
425 engineered for the insertion of heterologous env strain sequences and expression in cis of full426 length Env (pNL.CH058.ecto and pNL.YU-2.ecto), were previously described (47). In the same

427 study, isogenic proviral constructs encoding Renilla luciferase (LucR) followed in frame by a 428 ribosome-skipping T2A peptide intended to drive Nef expression were also reported (collectively 429 referred to as Env-IMC-LucR.T2A) (47). Construction of plasmids encoding for CH058 Vpu and $430 \mathrm{CH} 058 \mathrm{Nef}$ in the pCGCG-IRES-eGFP expression vector was previously described $(58,59)$.

432 Viral production and infections

433 To achieve a similar level of infection in primary $\mathrm{CD}^{+} \mathrm{T}$ cells among the different IMCs tested, 434 VSV-G-pseudotyped HIV-1 viruses were produced and titrated as previously described (120). 435 Viruses were then used to infect activated primary CD4+ T cells from healthy HIV-1 negative 436 donors by spin infection at $800 \times g$ for $1 \mathrm{~h}$ in 96 -well plates at $25^{\circ} \mathrm{C}$.

\section{Antibodies and plasma}

439 The following Abs were used to assess cell-surface Env staining: A32, $2 \mathrm{G} 12$ (NIH AIDS 440 Reagent Program) and PGT135 (IAVI). Mouse anti-human CD4 (clone OKT4; Thermo Fisher 441 Scientific, Waltham, MA, USA) and mouse anti-human BST-2 (clone RS38E, PE-Cy7442 conjugated; Biolegend, San Diego, CA, USA) were also used as primary antibodies for cell443 surface staining. Goat anti-mouse and anti-human antibodies pre-coupled to Alexa Fluor 647

444 (Invitrogen, Rockford, IL, USA) were used as secondary antibodies in flow cytometry 445 experiments. Plasma from HIV-infected individuals were collected, heat-inactivated and 446 conserved at $-80^{\circ} \mathrm{C}$ until use. Rabbit antisera raised against a Nef consensus protein (NIH AIDS

447 Reagent Program) or against a Vpu C-terminal peptide (69) were used as primary antibodies in 
448 intracellular staining. BrillantViolet 421 (BV421)-conjugated donkey anti-rabbit antibodies

449 (Biolegend) were used as secondary antibodies to detect Nef and Vpu antisera binding by flow

450 cytometry. To avoid any potential cross-reactivity with the anti-rabbit secondary antibodies used

451 for intracellular staining, mouse monoclonal antibodies were used to detect CD4 and BST-2

452 proteins.

453

$454 \quad$ Flow cytometry analysis of cell-surface and intracellular staining

455 Cell-surface staining of infected cells was performed as previously described (41). Binding of 456 cell-surface HIV-1 Env by anti-Env mAbs $(5 \mu \mathrm{g} / \mathrm{mL})$ or $\mathrm{HIV}+$ plasma $(1: 1000$ dilution $)$ was

457 performed at $48 \mathrm{~h}$ post-infection. Infected cells were then permeabilized using the 458 Cytofix/Cytoperm Fixation/ Permeabilization Kit (BD Biosciences, Mississauga, ON, Canada) 459 and stained intracellularly using PE-conjugated mouse anti-p24 mAb (clone KC57; Beckman 460 Coulter, Brea, CA, USA; 1:100 dilution) in combination with Nef or Vpu rabbit antisera (1:1000 461 dilution). The percentage of infected cells $\left(\mathrm{p} 24^{+}\right)$was determined by gating on the living cell 462 population according to a viability dye staining (Aqua Vivid; Thermo Fisher Scientific). 463 Alternatively, intracellular staining was assessed on 293T expressing Nef or Vpu proteins. 464 Briefly, 2x10 $293 \mathrm{~T}$ cells were transfected with 7 ug of Nef or Vpu expressor with the calcium465 phosphate method. At $48 \mathrm{~h}$ post transfection, 293T cells were stained intracellularly with rabbit 466 antisera raised against Nef or Vpu (1:1000). Samples were acquired on an LSRII cytometer (BD 467 Biosciences), and data analysis was performed using FlowJo v10.5.3 (Tree Star, Ashland, OR, 468 USA). 
471 Measurement of ADCC using the FACS-based assay was performed at $48 \mathrm{~h}$ post-infection as

472 previously described $(43,119)$. Briefly, HIV-1-infected primary CD4+ T cells were stained with

473 AquaVivid viability dye and cell proliferation dye eFluor670 (Thermo Fisher Scientific) and

474 used as target cells. Autologous PBMC effectors cells, stained with cell proliferation dye

475 eFluor450 (Thermo Fisher Scientific), were added at an effector: target ratio of 10:1 in 96-well

476 V-bottom plates (Corning, Corning, NY). A 1:1000 final dilution of plasma or $5 \mu \mathrm{g} / \mathrm{mL}$ of A32

$477 \mathrm{mAb}$ was added to appropriate wells and cells were incubated for $5 \mathrm{~min}$ at room temperature.

478 The plates were subsequently centrifuged for $1 \mathrm{~min}$ at $300 x \mathrm{~g}$, and incubated at $37^{\circ} \mathrm{C}, 5 \% \mathrm{CO}_{2}$

479 for $5 \mathrm{~h}$ before being fixed in a $2 \%$ PBS-formaldehyde solution. Samples were acquired on an 480 LSRII cytometer (BD Biosciences) and data analysis was performed using FlowJo v10.5.3 (Tree

481 Star). The percentage of ADCC was calculated with the following formula: (\% of p24+ cells in 482 Targets plus Effectors $)$ - (\% of p24+ cells in Targets plus Effectors plus plasma) / (\% of p24+ 483 cells in Targets) by gating on infected lived target cells.

\section{Software Scripts and Visualization}

486 Correlograms were generated using the corrplot package in program R v.4.1.012 and RStudio 487 v.1.4.1106 $(154,155)$. Correlation networks were created using the ggraph and igraph packages 488 in $\mathrm{R}$ in undirected mode, clustered based on the igraph layout "star". Edges are weighted 489 according to $\mathrm{P}$-values (inversely). Edges are only shown if $\mathrm{P}<0.05$, and nodes without edges 490 were removed. Nodes are sized according to the r-values of connecting edges. Multiple linear 491 regression analyses were performed using the GraphPad Prism software (version 9.1.0). The 492 coefficient of determination $\left(\mathrm{R}^{2}\right)$ was used as a metric to measure the proportion of the variation 493 observed with the dependant variable that can be explained by the variation in the independent 
494 variables. Since $\mathrm{R}^{2}$ values usually increases when more predictive variables are added to the 495 model, we also measured the adjusted $\mathrm{R}^{2}\left(\operatorname{adj} . \mathrm{R}^{2}\right)$ to account for this caveat.

496

497 Statistical analysis

498 Statistics were analyzed using GraphPad Prism version 9.1.0 (GraphPad, San Diego, CA, USA).

499 Every data set was tested for statistical normality and this information was used to apply the 500 appropriate (parametric or nonparametric) statistical test. P values $<0.05$ were considered 501 significant; significance values are indicated as * $\mathrm{P}<0.05, * * \mathrm{P}<0.01, * * * \mathrm{P}<0.001, * * * *$ $502 \quad \mathrm{P}<0.0001$.

503 
FIGURE LEGENDS

505

Figure 1. Intracellular detection of Nef and Vpu in infected primary CD4+ T cells.

507 (A-C) $293 \mathrm{~T}$ cells transfected with an empty vector or a plasmid expressing either CH058 Nef or CH058 Vpu. 48 hours post-transfection, cells were permeabilized and stained with rabbit

509 polyclonal antisera raised against Nef and Vpu to detect their respective intracellular expression.

510 Antiserum binding was detected using donkey anti-rabbit BV421 secondary Abs. (A) Histograms

511 depicting representative staining and (B-C) Median fluorescence intensities (MFI) obtained for

512 multiple independent stainings using (B) anti-Nef or (C) anti-Vpu. (D-G) Primary CD4+T cells

513 mock-infected or infected with $\mathrm{CH} 058 \mathrm{~T} / \mathrm{F}$ WT, Nef- or Vpu-, were stained to detect the

514 intracellular expression of Nef or Vpu. (D,F) Dot plots (left) and histograms (right) depicting

515 representative (D) Nef and (F) Vpu staining. (E,G) The graphs show the MFI obtained from

516 different cell populations using cells from five different donors using (E) anti-Nef or (G) anti-

517 Vpu. Error bars indicate means \pm standard errors of the means (SEM). Statistical significance

518 was tested using an unpaired t test or a Mann-Whitney $\mathrm{U}$ test based on statistical normality (*,

$519 \mathrm{P}<0.05 ; * *, \mathrm{P}<0.01 ; * * *, \mathrm{P}<0.001$; ns, nonsignificant). (H-I) Primary CD4+ $\mathrm{T}$ cells were

520 infected with a panel of viruses from different clades (A1, B, C, CRF01_AE), group (M, O) and

521 host (HIV-1, SIVcpz, SHIV). The radar plots indicate the level of specific recognition of infected

522 cells (MFI normalized to uninfected cells) using the (H) anti-Nef or (I) anti-Vpu antisera. The

523 limit of detection was determined using $(\mathbf{H})$ cells infected with CH058 Nef- for Nef staining and 
Figure 2. Concomitant detection of intracellular Nef and Vpu and cell-surface CD4 and

527

528

529

530

531

532

533

534

535

536

537

538

539

540

541

542

543

544

545

546

547

548

BST-2.

Primary CD4+T cells infected with CH058 T/F WT, Nef-, Vpu-, Vpu A14L/A18L or Vpu S52A/S56A viruses were stained for cell-surface CD4 and BST-2 prior to detection of intracellular Nef or Vpu expression. (A,C,E) Contour plots depicting representative cell-surface CD4 or BST-2 detection in combination with Nef or Vpu intracellular detection. Mock-infected cells were used as a control and are shown in grey. (B,D,F) The graphs show MFIs obtained from five independent experiments. Error bars indicate means \pm standard errors of the means (SEM). Statistical significance was tested using an unpaired t test or a Mann-Whitney U test based on statistical normality (*, $\mathrm{P}<0.05 ; * *, \mathrm{P}<0.01$; ***, $\mathrm{P}<0.001$; ns, nonsignificant).

\section{Figure 3. Nef and Vpu intracellular detection inversely correlates with the recognition of} infected cells and their susceptibility to ADCC responses mediated by HIV+ plasma.

Primary CD4+T cells were mock-infected (grey), infected with CH058 T/F (red) or JR-FL (Blue) viruses (WT, Nef-, Vpu-, Nef- Vpu-) and stained for (A) intracellular Nef or Vpu expression in combination with $(\mathbf{B})$ cell-surface staining of Env (using the anti-Env 2G12 mAb), CD4 and BST-2. The ability of the anti-Env A32 mAb and 25 different HIV+ plasma to (C) recognize infected cells and (D) eliminate infected cells by ADCC was also measured. (A-D) The graphs show the MFI obtained on the infected (p24+) cell population using cells from five different donors. Error bars indicate means \pm standard errors of the means (SEM). Statistical significance was tested using an unpaired t test or a Mann-Whitney $U$ test based on statistical normality (*, $\mathrm{P}<0.05 ; * *, \mathrm{P}<0.01 ; * * *, \mathrm{P}<0.001$; ns, nonsignificant). (E) Correlograms summarize pairwise correlations among all immunological, virological and cellular variables obtained from infected 
549 primary CD4+ T cells (shown in A-D). Squares are color-coded according to the magnitude of

550 the correlation coefficient (r) and the square dimensions are inversely proportional with the P-

551 values. Red squares represent a positive correlation between two variables and blue squares

552 represent negative correlations. Asterisks indicate all statistically significant correlations $(* \mathrm{P}<$

$5530.05, * * \mathrm{P}<0.01, * * * \mathrm{P}<0.005)$. Correlation analysis was done using nonparametric Spearman

554 rank tests. (F) Correlation networks were generated using data shown in (E). Each node (circle)

555 represents a cellular (red), an immunological (green) or a virological (blue) feature measured on

556 infected cells. Nodes are connected with edges (lines) if they are significantly correlated $(\mathrm{P}<$

557 0.05); nodes without edges were removed. Edges are weighted according to P-values (inversely).

558 Red edges represent a positive correlation between two variables and blue edges represent

559 negative correlations. Nodes are sized according to the r-values of connecting edges.

560

561 Figure 4. Lack of Nef expression in primary CD4+ T cells infected with LucR.T2A IMCs

562 results in enhanced ADCC.

563 Primary CD4+T cells mock-infected (grey) or infected with chimeric IMCs expressing CH058

564 Env (red) or YU-2 Env (green) and expressing or not the LucR reporter gene. (A) Dot plots

565 depicting representative stainings of intracellular Nef or Vpu expression. (B-C) Detection by

566 flow cytometry of (B) intracellular Nef or Vpu expression in combination with (C) cell-surface

567 staining of Env (using anti-Env mAbs 2G12 (CH058) or PGT135 (YU-2)), CD4 and BST-2. The

568 ability of the $\mathrm{A} 32 \mathrm{mAb}$ and $25 \mathrm{HIV}+$ plasma to (D) recognize infected cells and (E) eliminate

569 infected cells by ADCC was also measured. (B-E) The graphs show the MFI obtained on the

570 infected (p24+) cell population using cells from five different donors. Error bars indicate means

$571 \pm$ standard errors of the means (SEM). Statistical significance was tested using an unpaired t test 
572 or a Mann-Whitney $\mathrm{U}$ test based on statistical normality $(*, \mathrm{P}<0.05 ; * *, \mathrm{P}<0.01$; ***,

$573 \mathrm{P}<0.001$; ns, nonsignificant). (F) Correlograms summarize pairwise correlations among all

574 immunological, virological and cellular variables obtained from infected primary CD4+ T cells

575 (shown in B-E). Squares are color-coded according to the magnitude of the correlation

576 coefficient (r) and the square dimensions are inversely proportional with the P-values. Red

577 squares represent a positive correlation between two variables and blue squares represent

578 negative correlations. Asterisks indicate all statistically significant correlations $(* \mathrm{P}<0.05, * * \mathrm{P}<$

$5790.01, * * * \mathrm{P}<0.005)$. Correlation analysis was done using nonparametric Spearman rank tests.

580 (G) Correlation networks were generated using data shown in (F). Each node (circle) represents

581 a cellular (red), an immunological (green) or a virological (blue) feature measured on infected

582 cells. Nodes are connected with edges (lines) if they are significantly correlated $(\mathrm{P}<0.05)$; nodes

583 without edges were removed. Edges are weighted according to P-values (inversely). Red edges

584 represent a positive correlation between two variables and blue edges represent negative 585 correlations. Nodes are sized according to the r-values of connecting edges.

Figure 5. Prediction of ADCC responses mediated by HIV+ plasma using multiple linear regression models.

589 (A-C) Multiple linear regression analysis to identify variables that can predict the ADCC 590 responses mediated by HIV + plasma against primary CD4+ T cells infected by different viral 591 constructs (WT, Nef-, Vpu-, Nef-Vpu-, Env-IMC, Env-IMC-LucR.T2A) from different HIV-1 592 strains (CH058, JR-FL, YU-2). Each dot represents a single virus where the average of ADCC 593 obtained with 25 different HIV+ plasma (dependent variable) is plotted on the X axis and the 594 predicted ADCC value based on one or more independent parameters is plotted on the Y axis. 
595 Predictors include (A) cellular variables, (B) virological variables and (C) immunological 596 variables. Multiple linear regression analyses were performed using the GraphPad Prism 597 software (version 9.1.0). P values below 0.05 are considered significant and are highlighted in 598 bold. The coefficient of multiple correlation $\left(\mathrm{R}^{2}\right)$ indicates the goodness of fit of the multiple 599 regression linear model. The adjusted $\mathrm{R}^{2}\left(\operatorname{Adj} . \mathrm{R}^{2}\right)$ is used to compare the fits of models across 600 experiments with different numbers of data points and independent variables.

601

602 
624

625

626

627

628

629

630

631

632

633

634

635

636

637

638

639

640

641

642

643

644

645

646

647

648

649

650

\section{REFERENCES}

1. Desrosiers RC, Lifson JD, Gibbs JS, Czajak SC, Howe AY, Arthur LO, Johnson RP. 1998. Identification of highly attenuated mutants of simian immunodeficiency virus. $J$ Virol 72:1431-7.

2. Dave VP, Hajjar F, Dieng MM, Haddad E, Cohen EA. 2013. Efficient BST2 antagonism by $\mathrm{Vpu}$ is critical for early HIV-1 dissemination in humanized mice. Retrovirology 10:128.

3. Sato K, Misawa N, Fukuhara M, Iwami S, An DS, Ito M, Koyanagi Y. 2012. Vpu augments the initial burst phase of HIV-1 propagation and downregulates BST2 and CD4 in humanized mice. J Virol 86:5000-13.

4. Sato K, Misawa N, Iwami S, Satou Y, Matsuoka M, Ishizaka Y, Ito M, Aihara K, An DS, Koyanagi Y. 2013. HIV-1 Vpr accelerates viral replication during acute infection by exploitation of proliferating CD4+ T cells in vivo. PLoS Pathog 9:e1003812.

5. Crotti A, Neri F, Corti D, Ghezzi S, Heltai S, Baur A, Poli G, Santagostino E, Vicenzi E. 2006. Nef alleles from human immunodeficiency virus type 1-infected long-termnonprogressor hemophiliacs with or without late disease progression are defective in enhancing virus replication and CD4 down-regulation. J Virol 80:10663-74.

6. Rucker E, Grivel JC, Munch J, Kirchhoff F, Margolis L. 2004. Vpr and Vpu are important for efficient human immunodeficiency virus type 1 replication and CD4+ T-cell depletion in human lymphoid tissue ex vivo. J Virol 78:12689-93.

7. Kirchhoff F, Greenough TC, Brettler DB, Sullivan JL, Desrosiers RC. 1995. Brief report: absence of intact nef sequences in a long-term survivor with nonprogressive HIV-1 infection. N Engl J Med 332:228-32.

8. Haller C, Muller B, Fritz JV, Lamas-Murua M, Stolp B, Pujol FM, Keppler OT, Fackler OT. 2014. HIV-1 Nef and Vpu are functionally redundant broad-spectrum modulators of cell surface receptors, including tetraspanins. J Virol 88:14241-57.

9. Tokarev A, Guatelli J. 2011. Misdirection of membrane trafficking by HIV-1 Vpu and Nef: Keys to viral virulence and persistence. Cell Logist 1:90-102.

10. Purcell DF, Martin MA. 1993. Alternative splicing of human immunodeficiency virus type 1 mRNA modulates viral protein expression, replication, and infectivity. J Virol 67:636578.

11. Bentham M, Mazaleyrat S, Harris M. 2006. Role of myristoylation and N-terminal basic residues in membrane association of the human immunodeficiency virus type 1 Nef protein. J Gen Virol 87:563-571.

12. Craig HM, Reddy TR, Riggs NL, Dao PP, Guatelli JC. 2000. Interactions of HIV-1 nef with the mu subunits of adaptor protein complexes 1, 2, and 3: role of the dileucinebased sorting motif. Virology 271:9-17.

13. Chaudhuri R, Lindwasser OW, Smith WJ, Hurley JH, Bonifacino JS. 2007. Downregulation of CD4 by human immunodeficiency virus type $1 \mathrm{Nef}$ is dependent on clathrin and involves direct interaction of Nef with the AP2 clathrin adaptor. J Virol 81:3877-90.

14. Ren X, Park SY, Bonifacino JS, Hurley JH. 2014. How HIV-1 Nef hijacks the AP-2 clathrin adaptor to downregulate CD4. Elife 3:e01754.

15. Aiken C, Konner J, Landau NR, Lenburg ME, Trono D. 1994. Nef induces CD4 endocytosis: requirement for a critical dileucine motif in the membrane-proximal CD4 cytoplasmic domain. Cell 76:853-64.

16. Rhee SS, Marsh JW. 1994. Human immunodeficiency virus type 1 Nef-induced downmodulation of CD4 is due to rapid internalization and degradation of surface CD4. J Virol 68:5156-63. 
681

682

683

684

685

686

687

688

689

690

691

692

693

694

695

696

697

698

699

700

17. Schwartz S, Felber BK, Pavlakis GN. 1992. Mechanism of translation of monocistronic and multicistronic human immunodeficiency virus type 1 mRNAs. Mol Cell Biol 12:20719.

18. Krummheuer J, Johnson AT, Hauber I, Kammler S, Anderson JL, Hauber J, Purcell DF, Schaal H. 2007. A minimal uORF within the HIV-1 vpu leader allows efficient translation initiation at the downstream env AUG. Virology 363:261-71.

19. Wray V, Federau T, Henklein P, Klabunde S, Kunert O, Schomburg D, Schubert U. 1995. Solution structure of the hydrophilic region of HIV-1 encoded virus protein U (Vpu) by CD and 1H NMR spectroscopy. Int J Pept Protein Res 45:35-43.

20. Maldarelli F, Chen MY, Willey RL, Strebel K. 1993. Human immunodeficiency virus type $1 \mathrm{Vpu}$ protein is an oligomeric type I integral membrane protein. J Virol 67:5056-61.

21. Marassi FM, Ma C, Gratkowski H, Straus SK, Strebel K, Oblatt-Montal M, Montal M, Opella SJ. 1999. Correlation of the structural and functional domains in the membrane protein Vpu from HIV-1. Proc Natl Acad Sci U S A 96:14336-41.

22. Margottin F, Bour SP, Durand H, Selig L, Benichou S, Richard V, Thomas D, Strebel K, Benarous R. 1998. A novel human WD protein, h-beta TrCp, that interacts with HIV-1 Vpu connects CD4 to the ER degradation pathway through an F-box motif. Mol Cell 1:565-74.

23. Coadou G, Evrard-Todeschi N, Gharbi-Benarous J, Benarous R, Girault JP. 2002. HIV-1 encoded virus protein $U(\mathrm{Vpu})$ solution structure of the 41-62 hydrophilic region containing the phosphorylated sites Ser52 and Ser56. Int J Biol Macromol 30:23-40.

24. Dube M, Roy BB, Guiot-Guillain P, Mercier J, Binette J, Leung G, Cohen EA. 2009. Suppression of Tetherin-restricting activity upon human immunodeficiency virus type 1 particle release correlates with localization of $\mathrm{Vpu}$ in the trans-Golgi network. $\mathrm{J}$ Virol 83:4574-90.

25. Klimkait T, Strebel K, Hoggan MD, Martin MA, Orenstein JM. 1990. The human immunodeficiency virus type 1-specific protein vpu is required for efficient virus maturation and release. J Virol 64:621-9.

26. Schubert U, Strebel K. 1994. Differential activities of the human immunodeficiency virus type 1-encoded Vpu protein are regulated by phosphorylation and occur in different cellular compartments. J Virol 68:2260-71.

27. Schubert U, Anton LC, Bacik I, Cox JH, Bour S, Bennink JR, Orlowski M, Strebel K, Yewdell JW. 1998. CD4 glycoprotein degradation induced by human immunodeficiency virus type $1 \mathrm{Vpu}$ protein requires the function of proteasomes and the ubiquitinconjugating pathway. J Virol 72:2280-8.

28. Willey RL, Maldarelli F, Martin MA, Strebel K. 1992. Human immunodeficiency virus type $1 \mathrm{Vpu}$ protein induces rapid degradation of CD4. J Virol 66:7193-200.

29. Magadan JG, Perez-Victoria FJ, Sougrat R, Ye Y, Strebel K, Bonifacino JS. 2010. Multilayered mechanism of CD4 downregulation by HIV-1 Vpu involving distinct ER retention and ERAD targeting steps. PLoS Pathog 6:e1000869.

30. Neil SJ, Zang T, Bieniasz PD. 2008. Tetherin inhibits retrovirus release and is antagonized by HIV-1 Vpu. Nature 451:425-30.

31. Van Damme N, Goff D, Katsura C, Jorgenson RL, Mitchell R, Johnson MC, Stephens EB, Guatelli J. 2008. The interferon-induced protein BST-2 restricts HIV-1 release and is downregulated from the cell surface by the viral Vpu protein. Cell Host Microbe 3:24552.

32. Dube M, Roy BB, Guiot-Guillain P, Binette J, Mercier J, Chiasson A, Cohen EA. 2010. Antagonism of tetherin restriction of HIV-1 release by $\mathrm{Vpu}$ involves binding and sequestration of the restriction factor in a perinuclear compartment. PLoS Pathog 6:e1000856. 
33. Hauser H, Lopez LA, Yang SJ, Oldenburg JE, Exline CM, Guatelli JC, Cannon PM. 2010. HIV-1 Vpu and HIV-2 Env counteract BST-2/tetherin by sequestration in a perinuclear compartment. Retrovirology 7:51.

34. Wildum S, Schindler M, Munch J, Kirchhoff F. 2006. Contribution of Vpu, Env, and Nef to CD4 down-modulation and resistance of human immunodeficiency virus type 1-infected T cells to superinfection. J Virol 80:8047-59.

35. Ding S, Gasser R, Gendron-Lepage G, Medjahed H, Tolbert WD, Sodroski J, Pazgier M, Finzi A. 2019. CD4 Incorporation into HIV-1 Viral Particles Exposes Envelope Epitopes Recognized by CD4-Induced Antibodies. J Virol 93.

36. Bour S, Perrin C, Strebel K. 1999. Cell surface CD4 inhibits HIV-1 particle release by interfering with Vpu activity. J Biol Chem 274:33800-6.

37. Cortes MJ, Wong-Staal F, Lama J. 2002. Cell surface CD4 interferes with the infectivity of HIV-1 particles released from T cells. J Biol Chem 277:1770-9.

38. Lama J, Mangasarian A, Trono D. 1999. Cell-surface expression of CD4 reduces HIV-1 infectivity by blocking Env incorporation in a Nef- and Vpu-inhibitable manner. Curr Biol 9:622-31.

39. Levesque K, Zhao YS, Cohen EA. 2003. Vpu exerts a positive effect on HIV-1 infectivity by down-modulating CD4 receptor molecules at the surface of HIV-1-producing cells. J Biol Chem 278:28346-53.

40. Decker JM, Bibollet-Ruche F, Wei X, Wang S, Levy DN, Wang W, Delaporte E, Peeters M, Derdeyn CA, Allen S, Hunter E, Saag MS, Hoxie JA, Hahn BH, Kwong PD, Robinson JE, Shaw GM. 2005. Antigenic conservation and immunogenicity of the HIV coreceptor binding site. J Exp Med 201:1407-19.

41. Veillette M, Coutu M, Richard J, Batraville LA, Dagher O, Bernard N, Tremblay C, Kaufmann DE, Roger M, Finzi A. 2015. The HIV-1 gp120 CD4-Bound Conformation Is Preferentially Targeted by Antibody-Dependent Cellular Cytotoxicity-Mediating Antibodies in Sera from HIV-1-Infected Individuals. J Virol 89:545-51.

42. Guan Y, Pazgier M, Sajadi MM, Kamin-Lewis R, Al-Darmarki S, Flinko R, Lovo E, Wu X, Robinson JE, Seaman MS, Fouts TR, Gallo RC, DeVico AL, Lewis GK. 2013. Diverse specificity and effector function among human antibodies to HIV-1 envelope glycoprotein epitopes exposed by CD4 binding. Proc Natl Acad Sci U S A 110:E69-78.

43. Veillette M, Desormeaux A, Medjahed H, Gharsallah NE, Coutu M, Baalwa J, Guan Y, Lewis G, Ferrari G, Hahn BH, Haynes BF, Robinson JE, Kaufmann DE, Bonsignori M, Sodroski J, Finzi A. 2014. Interaction with cellular CD4 exposes HIV-1 envelope epitopes targeted by antibody-dependent cell-mediated cytotoxicity. J Virol 88:2633-44.

44. Alsahafi N, Ding S, Richard J, Markle T, Brassard N, Walker B, Lewis GK, Kaufmann DE, Brockman MA, Finzi A. 2016. Nef Proteins from HIV-1 Elite Controllers Are Inefficient at Preventing Antibody-Dependent Cellular Cytotoxicity. J Virol 90:2993-3002.

45. Schaefer MR, Wonderlich ER, Roeth JF, Leonard JA, Collins KL. 2008. HIV-1 Nef targets MHC-I and CD4 for degradation via a final common beta-COP-dependent pathway in T cells. PLoS Pathog 4:e1000131.

46. Dikeakos JD, Atkins KM, Thomas L, Emert-Sedlak L, Byeon IJ, Jung J, Ahn J, Wortman MD, Kukull B, Saito M, Koizumi H, Williamson DM, Hiyoshi M, Barklis E, Takiguchi M, Suzu S, Gronenborn AM, Smithgall TE, Thomas G. 2010. Small molecule inhibition of HIV-1-induced MHC-I down-regulation identifies a temporally regulated switch in Nef action. Mol Biol Cell 21:3279-92.

47. Edmonds TG, Ding H, Yuan X, Wei Q, Smith KS, Conway JA, Wieczorek L, Brown B, Polonis V, West JT, Montefiori DC, Kappes JC, Ochsenbauer C. 2010. Replication competent molecular clones of HIV-1 expressing Renilla luciferase facilitate the analysis of antibody inhibition in PBMC. Virology 408:1-13. 
48. Atkins KM, Thomas L, Youker RT, Harriff MJ, Pissani F, You H, Thomas G. 2008. HIV-1 Nef binds PACS-2 to assemble a multikinase cascade that triggers major histocompatibility complex class I (MHC-I) down-regulation: analysis using short interfering RNA and knock-out mice. J Biol Chem 283:11772-84.

49. Lenassi M, Cagney G, Liao M, Vaupotic T, Bartholomeeusen K, Cheng Y, Krogan NJ, Plemenitas A, Peterlin BM. 2010. HIV Nef is secreted in exosomes and triggers apoptosis in bystander CD4+ T cells. Traffic 11:110-22.

50. Komoto S, Tsuji S, Ibrahim MS, Li YG, Warachit J, Taniguchi K, Ikuta K. 2003. The vpu protein of human immunodeficiency virus type 1 plays a protective role against virusinduced apoptosis in primary CD4(+) T lymphocytes. J Virol 77:10304-13.

51. Miyagi E, Andrew AJ, Kao S, Strebel K. 2009. Vpu enhances HIV-1 virus release in the absence of Bst-2 cell surface down-modulation and intracellular depletion. Proc Natl Acad Sci U S A 106:2868-73.

52. Chu H, Wang JJ, Qi M, Yoon JJ, Chen X, Wen X, Hammonds J, Ding L, Spearman P. 2012. Tetherin/BST-2 is essential for the formation of the intracellular virus-containing compartment in HIV-infected macrophages. Cell Host Microbe 12:360-72.

53. Shugars DC, Smith MS, Glueck DH, Nantermet PV, Seillier-Moiseiwitsch F, Swanstrom R. 1993. Analysis of human immunodeficiency virus type 1 nef gene sequences present in vivo. J Virol 67:4639-50.

54. Alberti MO, Jones JJ, Miglietta R, Ding H, Bakshi RK, Edmonds TG, Kappes JC, Ochsenbauer C. 2015. Optimized Replicating Renilla Luciferase Reporter HIV-1 Utilizing Novel Internal Ribosome Entry Site Elements for Native Nef Expression and Function. AIDS Res Hum Retroviruses 31:1278-96.

55. Jacob RA, Edgar CR, Prevost J, Trothen SM, Lurie A, Mumby MJ, Galbraith A, Kirchhoff F, Haeryfar SMM, Finzi A, Dikeakos JD. 2021. The HIV-1 accessory protein Nef increases surface expression of the checkpoint receptor Tim-3 in infected CD4(+) T cells. J Biol Chem 297:101042.

56. Pawlak EN, Dirk BS, Jacob RA, Johnson AL, Dikeakos JD. 2018. The HIV-1 accessory proteins Nef and Vpu downregulate total and cell surface CD28 in CD4(+) T cells. Retrovirology 15:6.

57. Cohen EA, Terwilliger EF, Sodroski JG, Haseltine WA. 1988. Identification of a protein encoded by the vpu gene of HIV-1. Nature 334:532-4.

58. Heigele A, Kmiec D, Regensburger K, Langer S, Peiffer L, Sturzel CM, Sauter D, Peeters M, Pizzato M, Learn GH, Hahn BH, Kirchhoff F. 2016. The Potency of NefMediated SERINC5 Antagonism Correlates with the Prevalence of Primate Lentiviruses in the Wild. Cell Host Microbe 20:381-91.

59. Kmiec D, Iyer SS, Sturzel CM, Sauter D, Hahn BH, Kirchhoff F. 2016. Vpu-Mediated Counteraction of Tetherin Is a Major Determinant of HIV-1 Interferon Resistance. MBio 7.

60. Bolduan S, Hubel P, Reif T, Lodermeyer V, Hohne K, Fritz JV, Sauter D, Kirchhoff F, Fackler OT, Schindler M, Schubert U. 2013. HIV-1 Vpu affects the anterograde transport and the glycosylation pattern of NTB-A. Virology 440:190-203.

61. Bolduan S, Reif T, Schindler M, Schubert U. 2014. HIV-1 Vpu mediated downregulation of CD155 requires alanine residues 10,14 and 18 of the transmembrane domain. Virology 464-465:375-384.

62. Vassena L, Giuliani E, Koppensteiner H, Bolduan S, Schindler M, Doria M. 2015. HIV-1 Nef and Vpu Interfere with L-Selectin (CD62L) Cell Surface Expression To Inhibit Adhesion and Signaling in Infected CD4+ T Lymphocytes. J Virol 89:5687-700.

63. Prevost J, Pickering S, Mumby MJ, Medjahed H, Gendron-Lepage G, Delgado GG, Dirk BS, Dikeakos JD, Sturzel CM, Sauter D, Kirchhoff F, Bibollet-Ruche F, Hahn BH, Dube M, Kaufmann DE, Neil SJD, Finzi A, Richard J. 2019. Upregulation of BST-2 by Type I 
Interferons Reduces the Capacity of Vpu To Protect HIV-1-Infected Cells from NK Cell Responses. mBio 10.

64. Bour S, Schubert U, Strebel K. 1995. The human immunodeficiency virus type $1 \mathrm{Vpu}$ protein specifically binds to the cytoplasmic domain of CD4: implications for the mechanism of degradation. J Virol 69:1510-20.

65. Chen MY, Maldarelli F, Karczewski MK, Willey RL, Strebel K. 1993. Human immunodeficiency virus type $1 \mathrm{Vpu}$ protein induces degradation of CD4 in vitro: the cytoplasmic domain of CD4 contributes to Vpu sensitivity. J Virol 67:3877-84.

66. Lenburg ME, Landau NR. 1993. Vpu-induced degradation of CD4: requirement for specific amino acid residues in the cytoplasmic domain of CD4. J Virol 67:7238-45.

67. Vincent MJ, Raja NU, Jabbar MA. 1993. Human immunodeficiency virus type 1 Vpu protein induces degradation of chimeric envelope glycoproteins bearing the cytoplasmic and anchor domains of CD4: role of the cytoplasmic domain in Vpu-induced degradation in the endoplasmic reticulum. J Virol 67:5538-49.

68. Margottin F, Benichou S, Durand H, Richard V, Liu LX, Gomas E, Benarous R. 1996. Interaction between the cytoplasmic domains of HIV-1 Vpu and CD4: role of Vpu residues involved in CD4 interaction and in vitro CD4 degradation. Virology 223:381-6.

69. Prevost J, Edgar CR, Richard J, Trothen SM, Jacob RA, Mumby MJ, Pickering S, Dube M, Kaufmann DE, Kirchhoff F, Neil SJD, Finzi A, Dikeakos JD. 2020. HIV-1 Vpu Downregulates Tim-3 from the Surface of Infected CD4(+) T Cells. J Virol 94.

70. Binette J, Dube M, Mercier J, Halawani D, Latterich M, Cohen EA. 2007. Requirements for the selective degradation of CD4 receptor molecules by the human immunodeficiency virus type $1 \mathrm{Vpu}$ protein in the endoplasmic reticulum. Retrovirology 4:75.

71. Mitchell RS, Katsura C, Skasko MA, Fitzpatrick K, Lau D, Ruiz A, Stephens EB, Margottin-Goguet F, Benarous R, Guatelli JC. 2009. Vpu antagonizes BST-2-mediated restriction of HIV-1 release via beta-TrCP and endo-lysosomal trafficking. PLoS Pathog 5:e1000450.

72. Gustin JK, Douglas JL, Bai Y, Moses AV. 2012. Ubiquitination of BST-2 protein by HIV-1 $\mathrm{Vpu}$ protein does not require lysine, serine, or threonine residues within the BST-2 cytoplasmic domain. J Biol Chem 287:14837-50.

73. Belaidouni N, Marchal C, Benarous R, Besnard-Guerin C. 2007. Involvement of the betaTrCP in the ubiquitination and stability of the HIV-1 Vpu protein. Biochem Biophys Res Commun 357:688-93.

74. Kueck T, Neil SJ. 2012. A cytoplasmic tail determinant in HIV-1 Vpu mediates targeting of tetherin for endosomal degradation and counteracts interferon-induced restriction. PLoS Pathog 8:e1002609.

75. Kueck T, Foster TL, Weinelt J, Sumner JC, Pickering S, Neil SJ. 2015. Serine Phosphorylation of HIV-1 Vpu and Its Binding to Tetherin Regulates Interaction with Clathrin Adaptors. PLoS Pathog 11:e1005141.

76. Mangeat B, Gers-Huber G, Lehmann M, Zufferey M, Luban J, Piguet V. 2009. HIV-1 Vpu neutralizes the antiviral factor Tetherin/BST-2 by binding it and directing its beta-TrCP2dependent degradation. PLoS Pathog 5:e1000574.

77. Arias JF, Heyer LN, von Bredow B, Weisgrau KL, Moldt B, Burton DR, Rakasz EG, Evans DT. 2014. Tetherin antagonism by Vpu protects HIV-infected cells from antibodydependent cell-mediated cytotoxicity. Proc Natl Acad Sci U S A 111:6425-30.

78. Alvarez RA, Hamlin RE, Monroe A, Moldt B, Hotta MT, Rodriguez Caprio G, Fierer DS, Simon V, Chen BK. 2014. HIV-1 Vpu antagonism of tetherin inhibits antibody-dependent cellular cytotoxic responses by natural killer cells. J Virol 88:6031-46. 
79. Prevost J, Richard J, Medjahed H, Alexander A, Jones J, Kappes JC, Ochsenbauer C, Finzi A. 2018. Incomplete Downregulation of CD4 Expression Affects HIV-1 Env Conformation and Antibody-Dependent Cellular Cytotoxicity Responses. J Virol 92.

80. Ding S, Veillette M, Coutu M, Prevost J, Scharf L, Bjorkman PJ, Ferrari G, Robinson JE, Sturzel C, Hahn BH, Sauter D, Kirchhoff F, Lewis GK, Pazgier M, Finzi A. 2016. A Highly Conserved Residue of the HIV-1 gp120 Inner Domain Is Important for AntibodyDependent Cellular Cytotoxicity Responses Mediated by Anti-cluster A Antibodies. J Virol 90:2127-34.

81. Ferrari G, Pollara J, Kozink D, Harms T, Drinker M, Freel S, Moody MA, Alam SM, Tomaras GD, Ochsenbauer C, Kappes JC, Shaw GM, Hoxie JA, Robinson JE, Haynes BF. 2011. An HIV-1 gp120 envelope human monoclonal antibody that recognizes a C1 conformational epitope mediates potent antibody-dependent cellular cytotoxicity (ADCC) activity and defines a common ADCC epitope in human HIV-1 serum. J Virol 85:702936.

82. Tomaras GD, Ferrari G, Shen X, Alam SM, Liao HX, Pollara J, Bonsignori M, Moody MA, Fong Y, Chen X, Poling B, Nicholson CO, Zhang R, Lu X, Parks R, Kaewkungwal J, Nitayaphan S, Pitisuttithum P, Rerks-Ngarm S, Gilbert PB, Kim JH, Michael NL, Montefiori DC, Haynes BF. 2013. Vaccine-induced plasma IgA specific for the C1 region of the HIV-1 envelope blocks binding and effector function of IgG. Proc Natl Acad Sci U S A doi:10.1073/pnas.1301456110.

83. Pollara J, Bonsignori M, Moody MA, Liu P, Alam SM, Hwang KK, Gurley TC, Kozink DM, Armand LC, Marshall DJ, Whitesides JF, Kaewkungwal J, Nitayaphan S, Pitisuttithum P, Rerks-Ngarm S, Robb ML, O'Connell RJ, Kim JH, Michael NL, Montefiori DC, Tomaras GD, Liao HX, Haynes BF, Ferrari G. 2014. HIV-1 vaccine-induced C1 and V2 Envspecific antibodies synergize for increased antiviral activities. J Virol 88:7715-26.

84. Santra S, Tomaras GD, Warrier R, Nicely NI, Liao HX, Pollara J, Liu P, Alam SM, Zhang R, Cocklin SL, Shen X, Duffy R, Xia SM, Schutte RJ, Pemble Iv CW, Dennison SM, Li H, Chao A, Vidnovic K, Evans A, Klein K, Kumar A, Robinson J, Landucci G, Forthal DN, Montefiori DC, Kaewkungwal J, Nitayaphan S, Pitisuttithum P, Rerks-Ngarm S, Robb ML, Michael NL, Kim JH, Soderberg KA, Giorgi EE, Blair L, Korber BT, Moog C, Shattock RJ, Letvin NL, Schmitz JE, Moody MA, Gao F, Ferrari G, Shaw GM, Haynes BF. 2015. Human Non-neutralizing HIV-1 Envelope Monoclonal Antibodies Limit the Number of Founder Viruses during SHIV Mucosal Infection in Rhesus Macaques. PLoS Pathog 11:e1005042.

85. Huang Y, Ferrari G, Alter G, Forthal DN, Kappes JC, Lewis GK, Love JC, Borate B, Harris L, Greene K, Gao H, Phan TB, Landucci G, Goods BA, Dowell KG, Cheng HD, Bailey-Kellogg C, Montefiori DC, Ackerman ME. 2016. Diversity of Antiviral IgG Effector Activities Observed in HIV-Infected and Vaccinated Subjects. J Immunol 197:4603-4612.

86. Costa MR, Pollara J, Edwards RW, Seaman MS, Gorny MK, Montefiori DC, Liao HX, Ferrari G, Lu S, Wang S. 2016. Fc Receptor-Mediated Activities of Env-Specific Human Monoclonal Antibodies Generated from Volunteers Receiving the DNA Prime-Protein Boost HIV Vaccine DP6-001. J Virol 90:10362-10378.

87. Bradley T, Pollara J, Santra S, Vandergrift N, Pittala S, Bailey-Kellogg C, Shen X, Parks R, Goodman D, Eaton A, Balachandran H, Mach LV, Saunders KO, Weiner JA, Scearce R, Sutherland LL, Phogat S, Tartaglia J, Reed SG, Hu SL, Theis JF, Pinter A, Montefiori DC, Kepler TB, Peachman KK, Rao M, Michael NL, Suscovich TJ, Alter G, Ackerman ME, Moody MA, Liao HX, Tomaras G, Ferrari G, Korber BT, Haynes BF. 2017. Pentavalent HIV-1 vaccine protects against simian-human immunodeficiency virus challenge. Nat Commun 8:15711.

88. Meyerhoff RR, Scearce RM, Ogburn DF, Lockwood B, Pickeral J, Kuraoka M, Anasti K, Eudailey J, Eaton A, Cooper M, Wiehe K, Montefiori DC, Tomaras G, Ferrari G, Alam 
SM, Liao HX, Korber B, Gao F, Haynes BF. 2017. HIV-1 Consensus Envelope-Induced Broadly Binding Antibodies. AIDS Res Hum Retroviruses 33:859-868.

89. Sung JA, Pickeral J, Liu L, Stanfield-Oakley SA, Lam CK, Garrido C, Pollara J, LaBranche C, Bonsignori M, Moody MA, Yang Y, Parks R, Archin N, Allard B, Kirchherr J, Kuruc JD, Gay CL, Cohen MS, Ochsenbauer C, Soderberg K, Liao HX, Montefiori D, Moore P, Johnson S, Koenig S, Haynes BF, Nordstrom JL, Margolis DM, Ferrari G. 2015. Dual-Affinity Re-Targeting proteins direct T cell-mediated cytolysis of latently HIVinfected cells. J Clin Invest doi:10.1172/JCl82314.

90. Tuyishime M, Garrido C, Jha S, Moeser M, Mielke D, LaBranche C, Montefiori D, Haynes BF, Joseph S, Margolis DM, Ferrari G. 2020. Improved killing of HIV-infected cells using three neutralizing and non-neutralizing antibodies. J Clin Invest 130:51575170.

91. Bonsignori M, Pollara J, Moody MA, Alpert MD, Chen X, Hwang KK, Gilbert PB, Huang Y, Gurley TC, Kozink DM, Marshall DJ, Whitesides JF, Tsao CY, Kaewkungwal J, Nitayaphan S, Pitisuttithum P, Rerks-Ngarm S, Kim JH, Michael NL, Tomaras GD, Montefiori DC, Lewis GK, Devico A, Evans DT, Ferrari G, Liao HX, Haynes BF. 2012. Antibody-Dependent Cellular Cytotoxicity-Mediating Antibodies from an HIV-1 Vaccine Efficacy Trial Target Multiple Epitopes and Preferentially Use the VH1 Gene Family. J Virol 86:11521-32.

92. Cheng HD, Dowell KG, Bailey-Kellogg C, Goods BA, Love JC, Ferrari G, Alter G, Gach J, Forthal DN, Lewis GK, Greene K, Gao H, Montefiori DC, Ackerman ME. 2021. Diverse antiviral IgG effector activities are predicted by unique biophysical antibody features. Retrovirology 18:35.

93. Pollara J, Jones DI, Huffman T, Edwards RW, Dennis M, Li SH, Jha S, Goodman D, Kumar A, LaBranche CC, Montefiori DC, Fouda GG, Hope TJ, Tomaras GD, Staats HF, Ferrari G, Permar SR. 2019. Bridging Vaccine-Induced HIV-1 Neutralizing and Effector Antibody Responses in Rabbit and Rhesus Macaque Animal Models. J Virol 93.

94. Fisher L, Zinter M, Stanfield-Oakley S, Carpp LN, Edwards RW, Denny T, Moodie Z, Laher F, Bekker LG, McElrath MJ, Gilbert PB, Corey L, Tomaras G, Pollara J, Ferrari G. 2019. Vaccine-Induced Antibodies Mediate Higher Antibody-Dependent Cellular Cytotoxicity After Interleukin-15 Pretreatment of Natural Killer Effector Cells. Front Immunol 10:2741.

95. Lewis GK, Ackerman ME, Scarlatti G, Moog C, Robert-Guroff M, Kent SJ, Overbaugh J, Reeves RK, Ferrari G, Thyagarajan B. 2019. Knowns and Unknowns of Assaying Antibody-Dependent Cell-Mediated Cytotoxicity Against HIV-1. Front Immunol 10:1025.

96. Easterhoff D, Pollara J, Luo K, Tolbert WD, Young B, Mielke D, Jha S, O'Connell RJ, Vasan S, Kim J, Michael NL, Excler JL, Robb ML, Rerks-Ngarm S, Kaewkungwal J, Pitisuttithum P, Nitayaphan S, Sinangil F, Tartaglia J, Phogat S, Kepler TB, Alam SM, Wiehe K, Saunders KO, Montefiori DC, Tomaras GD, Moody MA, Pazgier M, Haynes BF, Ferrari G. 2020. Boosting with AIDSVAX B/E Enhances Env Constant Region 1 and 2 Antibody-Dependent Cellular Cytotoxicity Breadth and Potency. J Virol 94.

97. Tolbert WD, Van V, Sherburn R, Tuyishime M, Yan F, Nguyen DN, Stanfield-Oakley S, Easterhoff D, Bonsignori M, Haynes BF, Moody MA, Ray K, Ferrari G, Lewis GK, Pazgier M. 2020. Recognition Patterns of the C1/C2 Epitopes Involved in Fc-Mediated Response in HIV-1 Natural Infection and the RV114 Vaccine Trial. mBio 11.

98. Madani N, Princiotto AM, Mach L, Ding S, Prevost J, Richard J, Hora B, Sutherland L, Zhao CA, Conn BP, Bradley T, Moody MA, Melillo B, Finzi A, Haynes BF, Smith AB, III, Santra S, Sodroski J. 2018. A CD4-mimetic compound enhances vaccine efficacy against stringent immunodeficiency virus challenge. Nat Commun 9:2363.

99. Strebel K. 2013. HIV accessory proteins versus host restriction factors. Curr Opin Virol 3:692-9. 
984

985

986

987

988

989

990

991

992

993

994

995

996

997

998

999

1000

1001

1002

100. Ramirez PW, Famiglietti M, Sowrirajan B, DePaula-Silva AB, Rodesch C, Barker E, Bosque A, Planelles V. 2014. Downmodulation of CCR7 by HIV-1 Vpu results in impaired migration and chemotactic signaling within CD4(+) T cells. Cell Rep 7:2019-30.

101. Usami Y, Wu Y, Gottlinger HG. 2015. SERINC3 and SERINC5 restrict HIV-1 infectivity and are counteracted by Nef. Nature 526:218-23.

102. Rosa A, Chande A, Ziglio S, De Sanctis V, Bertorelli R, Goh SL, McCauley SM, Nowosielska A, Antonarakis SE, Luban J, Santoni FA, Pizzato M. 2015. HIV-1 Nef promotes infection by excluding SERINC5 from virion incorporation. Nature 526:212-7.

103. Liu Y, Fu Y, Wang Q, Li M, Zhou Z, Dabbagh D, Fu C, Zhang H, Li S, Zhang T, Gong J, Kong X, Zhai W, Su J, Sun J, Zhang Y, Yu XF, Shao Z, Zhou F, Wu Y, Tan X. 2019. Proteomic profiling of HIV-1 infection of human CD4(+) T cells identifies PSGL-1 as an HIV restriction factor. Nat Microbiol 4:813-825.

104. Fu Y, He S, Waheed AA, Dabbagh D, Zhou Z, Trinite B, Wang Z, Yu J, Wang D, Li F, Levy DN, Shang H, Freed EO, Wu Y. 2020. PSGL-1 restricts HIV-1 infectivity by blocking virus particle attachment to target cells. Proc Natl Acad Sci U S A 117:95379545.

105. Schwartz O, Marechal V, Le Gall S, Lemonnier F, Heard JM. 1996. Endocytosis of major histocompatibility complex class I molecules is induced by the HIV-1 Nef protein. Nat Med 2:338-42.

106. Collins KL, Chen BK, Kalams SA, Walker BD, Baltimore D. 1998. HIV-1 Nef protein protects infected primary cells against killing by cytotoxic $\mathrm{T}$ lymphocytes. Nature 391:397-401.

107. Cerboni C, Neri F, Casartelli N, Zingoni A, Cosman D, Rossi P, Santoni A, Doria M. 2007. Human immunodeficiency virus 1 Nef protein downmodulates the ligands of the activating receptor NKG2D and inhibits natural killer cell-mediated cytotoxicity. J Gen Virol 88:242-50.

108. Fausther-Bovendo H, Sol-Foulon N, Candotti D, Agut H, Schwartz O, Debre P, Vieillard V. 2009. HIV escape from natural killer cytotoxicity: nef inhibits NKp44L expression on CD4+ T cells. AIDS 23:1077-87.

109. Shah AH, Sowrirajan B, Davis ZB, Ward JP, Campbell EM, Planelles V, Barker E. 2010. Degranulation of natural killer cells following interaction with HIV-1-infected cells is hindered by downmodulation of NTB-A by Vpu. Cell Host Microbe 8:397-409.

110. Matusali G, Potesta M, Santoni A, Cerboni C, Doria M. 2012. The human immunodeficiency virus type $1 \mathrm{Nef}$ and $\mathrm{Vpu}$ proteins downregulate the natural killer cellactivating ligand PVR. J Virol 86:4496-504.

111. Apps R, Del Prete GQ, Chatterjee P, Lara A, Brumme ZL, Brockman MA, Neil S, Pickering S, Schneider DK, Piechocka-Trocha A, Walker BD, Thomas R, Shaw GM, Hahn BH, Keele BF, Lifson JD, Carrington M. 2016. HIV-1 Vpu Mediates HLA-C Downregulation. Cell Host Microbe 19:686-95.

112. Moll M, Andersson SK, Smed-Sorensen A, Sandberg JK. 2010. Inhibition of lipid antigen presentation in dendritic cells by HIV-1 Vpu interference with CD1d recycling from endosomal compartments. Blood 116:1876-84.

113. Chen N, McCarthy C, Drakesmith H, Li D, Cerundolo V, McMichael AJ, Screaton GR, Xu XN. 2006. HIV-1 down-regulates the expression of CD1d via Nef. Eur J Immunol 36:27886.

114. Pacyniak E, Gomez ML, Gomez LM, Mulcahy ER, Jackson M, Hout DR, Wisdom BJ, Stephens EB. 2005. Identification of a region within the cytoplasmic domain of the subtype B Vpu protein of human immunodeficiency virus type 1 (HIV-1) that is responsible for retention in the golgi complex and its absence in the $\mathrm{Vpu}$ protein from a subtype C HIV-1. AIDS Res Hum Retroviruses 21:379-94. 
1003

1004

1005

1006

1007

1008

1009

1010

1011

1012

1013

1014

1015

1016

1017

1018

1019

1020

1021

1022

1023

1024

1025

1026

1027

1028

1029

1030

1031

1032

1033

1034

1035

1036

1037

1038

1039

1040

1041

1042

1043

1044

1045

1046

1047

1048

1049

1050

1051
115. Sharma S, Jafari M, Bangar A, William K, Guatelli J, Lewinski MK. 2019. The C-Terminal End of HIV-1 Vpu Has a Clade-Specific Determinant That Antagonizes BST-2 and Facilitates Virion Release. J Virol 93.

116. Pickering S, Hue S, Kim EY, Reddy S, Wolinsky SM, Neil SJ. 2014. Preservation of Tetherin and CD4 Counter-Activities in Circulating Vpu Alleles despite Extensive Sequence Variation within HIV-1 Infected Individuals. PLoS Pathog 10:e1003895.

117. Iwami S, Sato K, Morita S, Inaba H, Kobayashi T, Takeuchi JS, Kimura Y, Misawa N, Ren F, Iwasa Y, Aihara K, Koyanagi Y. 2015. Pandemic HIV-1 Vpu overcomes intrinsic herd immunity mediated by tetherin. Sci Rep 5:12256.

118. Chen BK, Gandhi RT, Baltimore D. 1996. CD4 down-modulation during infection of human $T$ cells with human immunodeficiency virus type 1 involves independent activities of vpu, env, and nef. J Virol 70:6044-53.

119. Richard J, Veillette M, Brassard N, lyer SS, Roger M, Martin L, Pazgier M, Schon A, Freire E, Routy JP, Smith AB, III, Park J, Jones DM, Courter JR, Melillo BN, Kaufmann DE, Hahn BH, Permar SR, Haynes BF, Madani N, Sodroski JG, Finzi A. 2015. CD4 mimetics sensitize HIV-1-infected cells to ADCC. Proc Natl Acad Sci U S A 112:E268794.

120. Prevost J, Zoubchenok D, Richard J, Veillette M, Pacheco B, Coutu M, Brassard N, Parsons MS, Ruxrungtham K, Bunupuradah T, Tovanabutra S, Hwang KK, Moody MA, Haynes BF, Bonsignori M, Sodroski J, Kaufmann DE, Shaw GM, Chenine AL, Finzi A. 2017. Influence of the Envelope gp120 Phe 43 Cavity on HIV-1 Sensitivity to AntibodyDependent Cell-Mediated Cytotoxicity Responses. J Virol 91.

121. Prevost J, Richard J, Ding S, Pacheco B, Charlebois R, Hahn BH, Kaufmann DE, Finzi A. 2018. Envelope glycoproteins sampling states $2 / 3$ are susceptible to ADCC by sera from HIV-1-infected individuals. Virology 515:38-45.

122. Richard J, Prevost J, von Bredow B, Ding S, Brassard N, Medjahed H, Coutu M, Melillo B, Bibollet-Ruche F, Hahn BH, Kaufmann DE, Smith AB, 3rd, Sodroski J, Sauter D, Kirchhoff F, Gee K, Neil SJ, Evans DT, Finzi A. 2017. BST-2 Expression Modulates Small CD4-Mimetic Sensitization of HIV-1-Infected Cells to Antibody-Dependent Cellular Cytotoxicity. J Virol 91.

123. Mielke D, Stanfield-Oakley S, Borate B, Fisher LH, Faircloth K, Tuyishime M, Greene K, Gao H, Williamson C, Morris L, Ochsenbauer C, Tomaras G, Haynes BF, Montefiori D, Pollara J, deCamp AC, Ferrari G. 2021. Selection of HIV Envelope strains for standardized assessments of vaccine-elicited antibody-dependent cellular cytotoxicity (ADCC)-mediating antibodies. J Virol doi:10.1128/JVI.01643-21:JVI0164321.

124. Prevost J, Tolbert WD, Medjahed H, Sherburn RT, Madani N, Zoubchenok D, GendronLepage G, Gaffney AE, Grenier MC, Kirk S, Vergara N, Han C, Mann BT, Chenine AL, Ahmed A, Chaiken I, Kirchhoff F, Hahn BH, Haim H, Abrams CF, Smith AB, III, Sodroski J, Pazgier M, Finzi A. 2020. The HIV-1 Env gp120 Inner Domain Shapes the Phe43 Cavity and the CD4 Binding Site. mBio 11.

125. Richard J, Prevost J, Alsahafi N, Ding S, Finzi A. 2018. Impact of HIV-1 Envelope Conformation on ADCC Responses. Trends Microbiol 26:253-265.

126. Alpert MD, Heyer LN, Williams DE, Harvey JD, Greenough T, Allhorn M, Evans DT. 2012. A novel assay for antibody-dependent cell-mediated cytotoxicity against HIV-1- or SIV-infected cells reveals incomplete overlap with antibodies measured by neutralization and binding assays. J Virol 86:12039-52.

127. Fontaine J, Chagnon-Choquet J, Valcke HS, Poudrier J, Roger M. 2011. High expression levels of B lymphocyte stimulator (BLyS) by dendritic cells correlate with HIVrelated B-cell disease progression in humans. Blood 117:145-55. 
1052

1053

1054

1055

1056

1057

1058

1059

1060

1061

1062

1063

1064

1065

1066

1067

1068

1069

1070

1071

1072

1073

1074

1075

1076

1077

1078

1079

1080

1081

1082

1083

1084

1085

1086

1087

1088

1089

1090

1091

1092

1093

1094

1095

1096

1097

1098

1099

1100

1101
128. Fontaine J, Coutlee F, Tremblay C, Routy JP, Poudrier J, Roger M. 2009. HIV infection affects blood myeloid dendritic cells after successful therapy and despite nonprogressing clinical disease. J Infect Dis 199:1007-18.

129. International HIVCS, Pereyra F, Jia X, McLaren PJ, Telenti A, de Bakker PI, Walker BD, Ripke S, Brumme CJ, Pulit SL, Carrington M, Kadie CM, Carlson JM, Heckerman D, Graham RR, Plenge RM, Deeks SG, Gianniny L, Crawford G, Sullivan J, Gonzalez E, Davies L, Camargo A, Moore JM, Beattie N, Gupta S, Crenshaw A, Burtt NP, Guiducci C, Gupta N, Gao X, Qi Y, Yuki Y, Piechocka-Trocha A, Cutrell E, Rosenberg R, Moss KL, Lemay P, O'Leary J, Schaefer T, Verma P, Toth I, Block B, Baker B, Rothchild A, Lian J, Proudfoot J, Alvino DM, Vine S, Addo MM, et al. 2010. The major genetic determinants of HIV-1 control affect HLA class I peptide presentation. Science 330:1551-7.

130. Kamya P, Boulet S, Tsoukas CM, Routy JP, Thomas R, Cote P, Boulassel MR, Baril JG, Kovacs C, Migueles SA, Connors M, Suscovich TJ, Brander C, Tremblay CL, Bernard N. 2011. Receptor-ligand requirements for increased NK cell polyfunctional potential in slow progressors infected with HIV-1 coexpressing KIR3DL $1^{*} \mathrm{~h} /{ }^{*} \mathrm{y}$ and HLA-B*57. J Virol 85:5949-60.

131. Peretz Y, Ndongala ML, Boulet S, Boulassel MR, Rouleau D, Cote P, Longpre D, Routy JP, Falutz J, Tremblay C, Tsoukas CM, Sekaly RP, Bernard NF. 2007. Functional T cell subsets contribute differentially to HIV peptide-specific responses within infected individuals: correlation of these functional $T$ cell subsets with markers of disease progression. Clin Immunol 124:57-68.

132. Finzi A, Xiang SH, Pacheco B, Wang L, Haight J, Kassa A, Danek B, Pancera M, Kwong PD, Sodroski J. 2010. Topological layers in the HIV-1 gp120 inner domain regulate gp41 interaction and CD4-triggered conformational transitions. Mol Cell 37:656-67.

133. Emi N, Friedmann T, Yee JK. 1991. Pseudotype formation of murine leukemia virus with the $G$ protein of vesicular stomatitis virus. J Virol 65:1202-7.

134. Salazar-Gonzalez JF, Salazar MG, Keele BF, Learn GH, Giorgi EE, Li H, Decker JM, Wang S, Baalwa J, Kraus MH, Parrish NF, Shaw KS, Guffey MB, Bar KJ, Davis KL, Ochsenbauer-Jambor C, Kappes JC, Saag MS, Cohen MS, Mulenga J, Derdeyn CA, Allen S, Hunter E, Markowitz M, Hraber P, Perelson AS, Bhattacharya T, Haynes BF, Korber BT, Hahn BH, Shaw GM. 2009. Genetic identity, biological phenotype, and evolutionary pathways of transmitted/founder viruses in acute and early HIV-1 infection. J Exp Med 206:1273-89.

135. Ochsenbauer C, Edmonds TG, Ding H, Keele BF, Decker J, Salazar MG, SalazarGonzalez JF, Shattock R, Haynes BF, Shaw GM, Hahn BH, Kappes JC. 2012. Generation of Transmitted/Founder HIV-1 Infectious Molecular Clones and Characterization of Their Replication Capacity in CD4 T Lymphocytes and MonocyteDerived Macrophages. J Virol 86:2715-28.

136. Parrish NF, Wilen CB, Banks LB, lyer SS, Pfaff JM, Salazar-Gonzalez JF, Salazar MG, Decker JM, Parrish EH, Berg A, Hopper J, Hora B, Kumar A, Mahlokozera T, Yuan S, Coleman C, Vermeulen M, Ding H, Ochsenbauer C, Tilton JC, Permar SR, Kappes JC, Betts MR, Busch MP, Gao F, Montefiori D, Haynes BF, Shaw GM, Hahn BH, Doms RW. 2012. Transmitted/founder and chronic subtype C HIV-1 use CD4 and CCR5 receptors with equal efficiency and are not inhibited by blocking the integrin alpha4beta7. PLoS Pathog 8:e1002686.

137. Parrish NF, Gao F, Li H, Giorgi EE, Barbian HJ, Parrish EH, Zajic L, lyer SS, Decker JM, Kumar A, Hora B, Berg A, Cai F, Hopper J, Denny TN, Ding H, Ochsenbauer C, Kappes JC, Galimidi RP, West AP, Jr., Bjorkman PJ, Wilen CB, Doms RW, O'Brien M, Bhardwaj N, Borrow P, Haynes BF, Muldoon M, Theiler JP, Korber B, Shaw GM, Hahn BH. 2013. 
1134

1135

1136

1137

1138

1139

1140

1141

1142

1143

1144

1145

1146

1147

1148

1149

1150

1151

Phenotypic properties of transmitted founder HIV-1. Proc Natl Acad Sci U S A 110:662633.

138. Fenton-May AE, Dibben O, Emmerich T, Ding H, Pfafferott K, Aasa-Chapman MM, Pellegrino P, Williams I, Cohen MS, Gao F, Shaw GM, Hahn BH, Ochsenbauer C, Kappes JC, Borrow P. 2013. Relative resistance of HIV-1 founder viruses to control by interferon-alpha. Retrovirology 10:146.

139. Liao HX, Lynch R, Zhou T, Gao F, Alam SM, Boyd SD, Fire AZ, Roskin KM, Schramm CA, Zhang Z, Zhu J, Shapiro L, Mullikin JC, Gnanakaran S, Hraber P, Wiehe K, Kelsoe G, Yang G, Xia SM, Montefiori DC, Parks R, Lloyd KE, Scearce RM, Soderberg KA, Cohen M, Kamanga G, Louder MK, Tran LM, Chen Y, Cai F, Chen S, Moquin S, Du X, Joyce MG, Srivatsan S, Zhang B, Zheng A, Shaw GM, Hahn BH, Kepler TB, Korber BT, Kwong PD, Mascola JR, Haynes BF. 2013. Co-evolution of a broadly neutralizing HIV-1 antibody and founder virus. Nature 496:469-76.

140. Gao F, Bonsignori M, Liao HX, Kumar A, Xia SM, Lu X, Cai F, Hwang KK, Song H, Zhou T, Lynch RM, Alam SM, Moody MA, Ferrari G, Berrong M, Kelsoe G, Shaw GM, Hahn $\mathrm{BH}$, Montefiori DC, Kamanga G, Cohen MS, Hraber P, Kwong PD, Korber BT, Mascola JR, Kepler TB, Haynes BF. 2014. Cooperation of B cell lineages in induction of HIV-1broadly neutralizing antibodies. Cell 158:481-91.

141. Salminen MO, Ehrenberg PK, Mascola JR, Dayhoff DE, Merling R, Blake B, Louder M, Hegerich S, Polonis VR, Birx DL, Robb ML, McCutchan FE, Michael NL. 2000. Construction and biological characterization of infectious molecular clones of HIV-1 subtypes $B$ and E (CRF01_AE) generated by the polymerase chain reaction. Virology 278:103-10.

142. Chenine AL, Merbah M, Wieczorek L, Molnar S, Mann B, Lee J, O'Sullivan AM, Bose M, Sanders-Buell E, Kijak GH, Herrera C, McLinden R, O'Connell RJ, Michael NL, Robb ML, Kim JH, Polonis VR, Tovanabutra S. 2018. Neutralization Sensitivity of a Novel HIV1 CRF01_AE Panel of Infectious Molecular Clones. J Acquir Immune Defic Syndr 78:348-355.

143. Peachman KK, Karasavvas N, Chenine AL, McLinden R, Rerks-Ngarm S, Jaranit K, Nitayaphan S, Pitisuttithum P, Tovanabutra S, Zolla-Pazner S, Michael NL, Kim JH, Alving CR, Rao M. 2015. Identification of New Regions in HIV-1 gp120 Variable 2 and 3 Loops that Bind to alpha4beta7 Integrin Receptor. PLoS One 10:e0143895.

144. O'Brien WA, Koyanagi Y, Namazie A, Zhao JQ, Diagne A, Idler K, Zack JA, Chen IS. 1990. HIV-1 tropism for mononuclear phagocytes can be determined by regions of gp120 outside the CD4-binding domain. Nature 348:69-73.

145. Li Y, Kappes JC, Conway JA, Price RW, Shaw GM, Hahn BH. 1991. Molecular characterization of human immunodeficiency virus type 1 cloned directly from uncultured human brain tissue: identification of replication-competent and -defective viral genomes. J Virol 65:3973-85.

146. Theodore TS, Englund G, Buckler-White A, Buckler CE, Martin MA, Peden KW. 1996. Construction and characterization of a stable full-length macrophage-tropic HIV type 1 molecular clone that directs the production of high titers of progeny virions. AIDS Res Hum Retroviruses 12:191-4.

147. Krapp C, Hotter D, Gawanbacht A, McLaren PJ, Kluge SF, Sturzel CM, Mack K, Reith E, Engelhart S, Ciuffi A, Hornung V, Sauter D, Telenti A, Kirchhoff F. 2016. Guanylate Binding Protein (GBP) 5 Is an Interferon-Inducible Inhibitor of HIV-1 Infectivity. Cell Host Microbe 19:504-14.

148. Koyanagi Y, Miles S, Mitsuyasu RT, Merrill JE, Vinters HV, Chen IS. 1987. Dual infection of the central nervous system by AIDS viruses with distinct cellular tropisms. Science 236:819-22. 
149. Adachi A, Gendelman HE, Koenig S, Folks T, Willey R, Rabson A, Martin MA. 1986. Production of acquired immunodeficiency syndrome-associated retrovirus in human and nonhuman cells transfected with an infectious molecular clone. J Virol 59:284-91.

150. Mack K, Starz K, Sauter D, Langer S, Bibollet-Ruche F, Learn GH, Sturzel CM, Leoz M, Plantier JC, Geyer M, Hahn BH, Kirchhoff F. 2017. Efficient Vpu-Mediated Tetherin Antagonism by an HIV-1 Group O Strain. J Virol 91.

151. Takehisa J, Kraus MH, Decker JM, Li Y, Keele BF, Bibollet-Ruche F, Zammit KP, Weng Z, Santiago ML, Kamenya S, Wilson ML, Pusey AE, Bailes E, Sharp PM, Shaw GM, Hahn BH. 2007. Generation of infectious molecular clones of simian immunodeficiency virus from fecal consensus sequences of wild chimpanzees. J Virol 81:7463-75.

152. Shingai M, Donau OK, Schmidt SD, Gautam R, Plishka RJ, Buckler-White A, Sadjadpour R, Lee WR, LaBranche CC, Montefiori DC, Mascola JR, Nishimura Y, Martin MA. 2012. Most rhesus macaques infected with the CCR5-tropic SHIV(AD8) generate cross-reactive antibodies that neutralize multiple HIV-1 strains. Proc Natl Acad Sci U S A 109:19769-74.

153. Li H, Wang S, Lee FH, Roark RS, Murphy AI, Smith J, Zhao C, Rando J, Chohan N, Ding Y, Kim E, Lindemuth E, Bar KJ, Pandrea I, Apetrei C, Keele BF, Lifson JD, Lewis MG, Denny TN, Haynes BF, Hahn BH, Shaw GM. 2021. New SHIVs and Improved Design Strategy for Modeling HIV-1 Transmission, Immunopathogenesis, Prevention and Cure. J Virol doi:10.1128/JVI.00071-21.

1171

1172

1173

1174

1175

154. R Core Team. 2013. R: A language and environment for statistical computing, R Foundation for Statistical Computing, Vienna, Austria. https://www.R-project.org/.

155. RStudio team. 2015. RStudio: Integrated Development for R, RStudio, Inc., Boston, MA. http://www.rstudio.com/. 
A
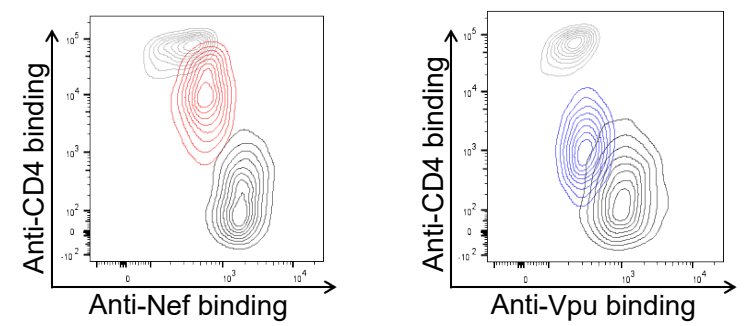

CH058 Vpu-

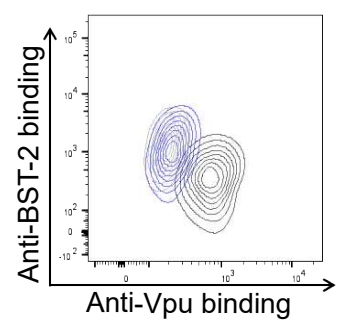

B

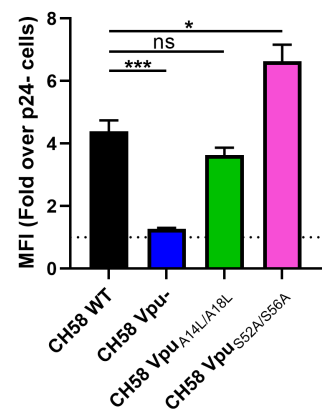

D

CH058 Vpu- $\quad \mathrm{CH}_{058} \mathrm{Vpu}_{\mathrm{A} 14 L / A 18 L} \quad \mathrm{CH}_{058} \mathrm{Vpu}_{\text {S52A/S56A }}$
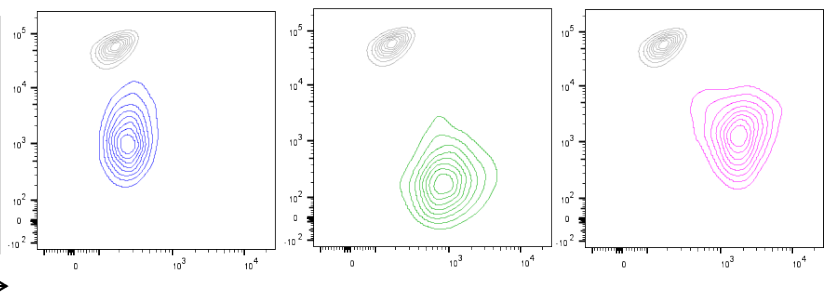

C
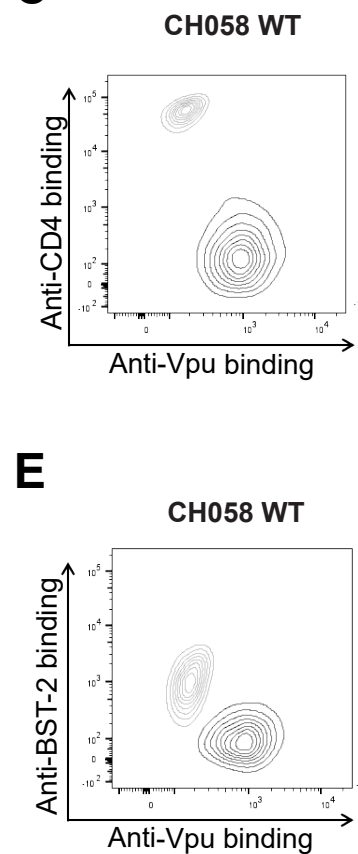

CH058 Vpu-

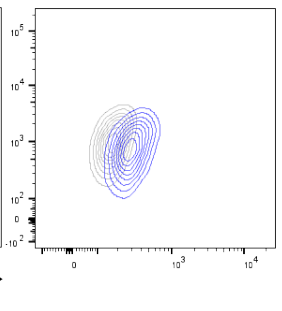

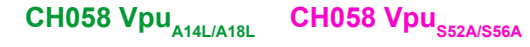

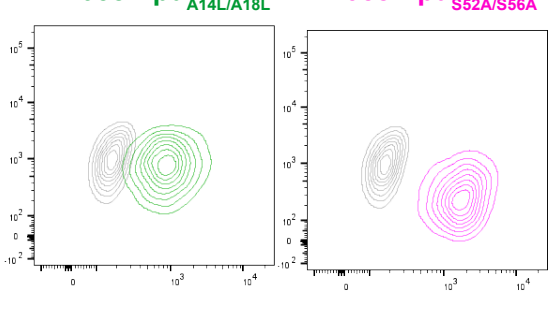

F
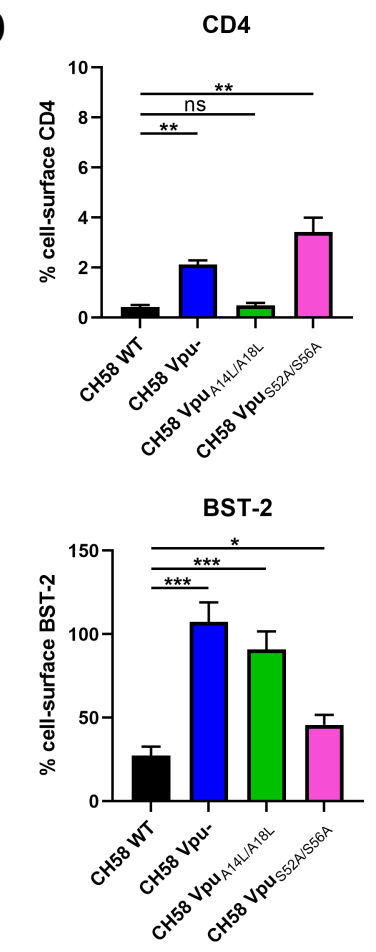
A

○ mock o $\mathrm{CH} 058$ ○ JR-FL
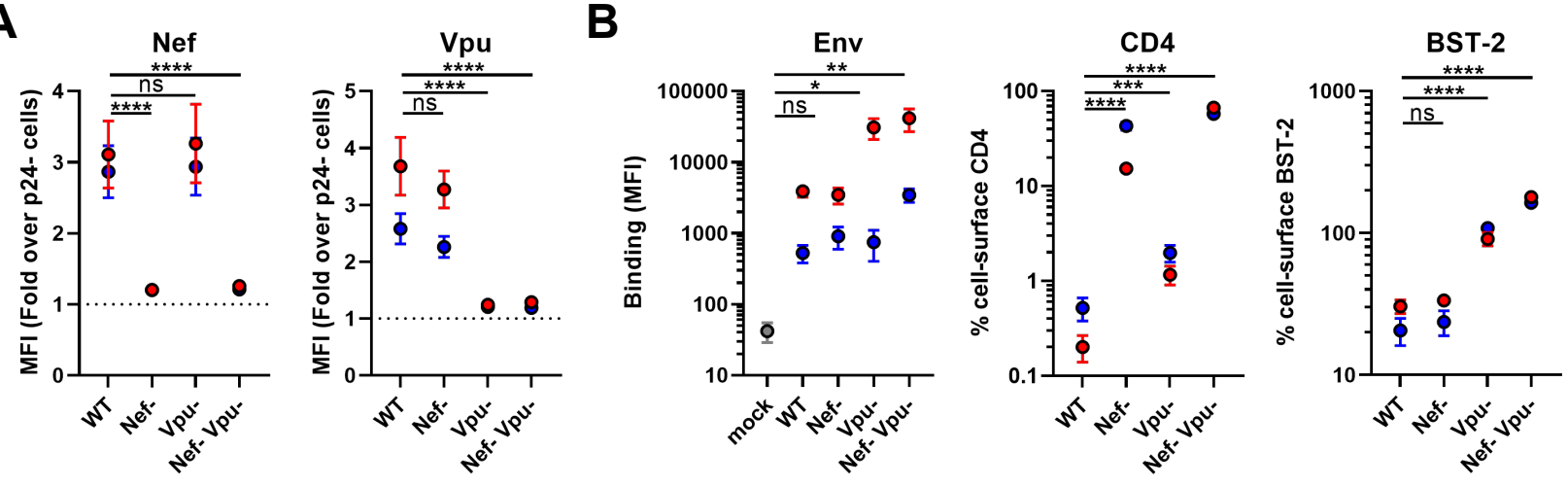

C
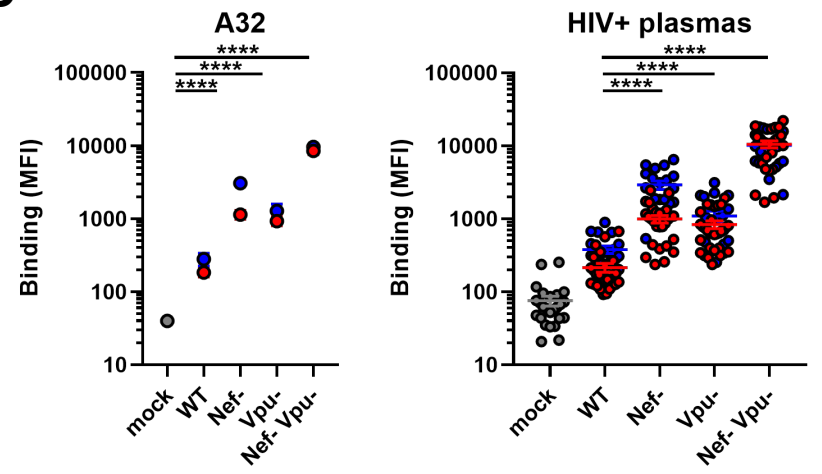

E

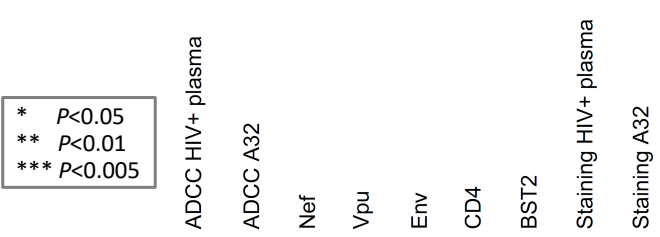

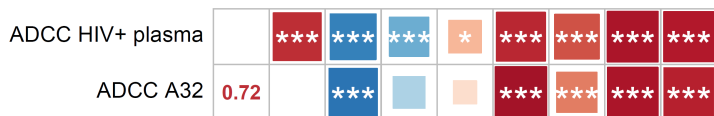
Nef $-0.66-0.73$ $* * * \quad * * * * * * *$

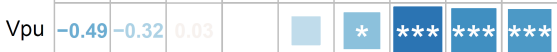
\begin{tabular}{l|l|l|l|l|l|l|l|l|} 
Env & 0.33 & 0.17 & 0 & -0.24 & & & $* * * *$
\end{tabular}

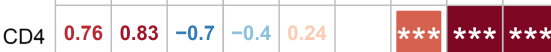

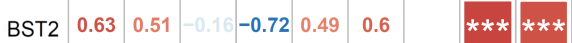
\begin{tabular}{|l|l|l|l|l|l|l|l|l|} 
Staining HIV+ plasma & 0.81 & 0.8 & -0.6 & -0.61 & 0.25 & 0.93 & 0.67 & $* * *$ \\
\hline
\end{tabular} \begin{tabular}{l|l|l|l|l|l|l|l|l|} 
Staining A32 & 0.79 & 0.77 & -0.6 & -0.57 & 0.27 & $\mathbf{0 . 9 3}$ & 0.64 & $\mathbf{0 . 9 6}$
\end{tabular}
D
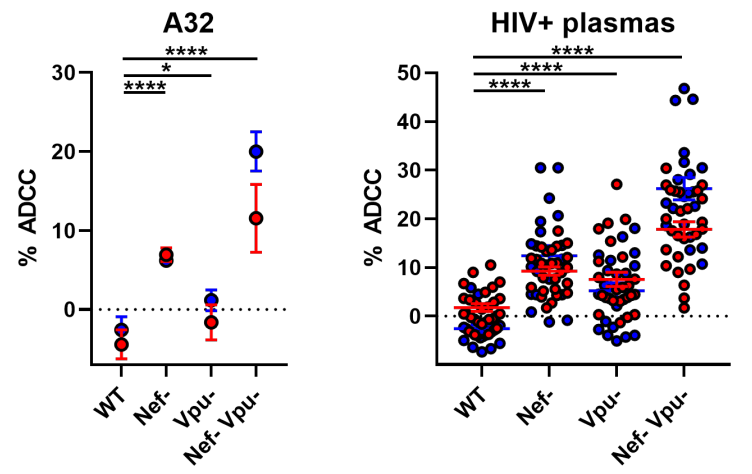

F

Type

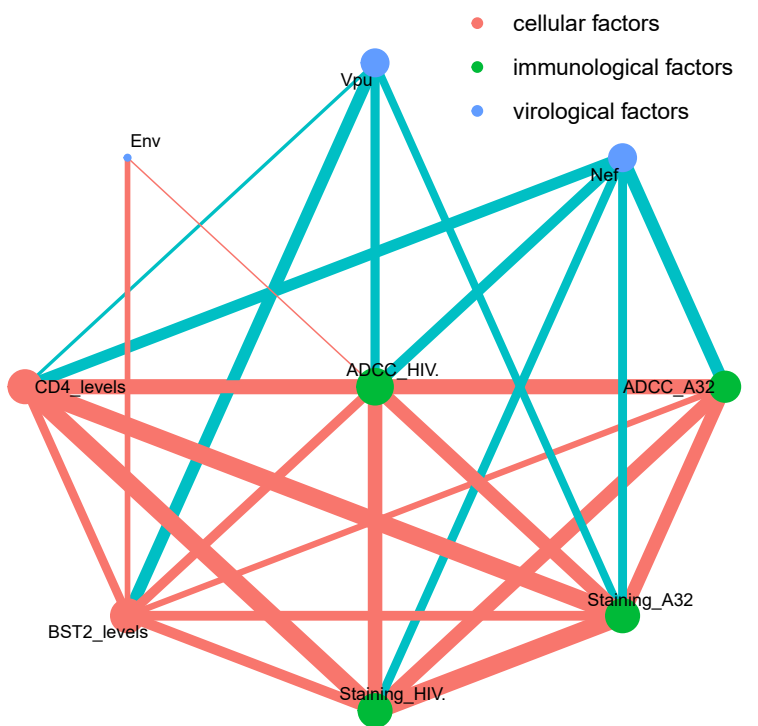




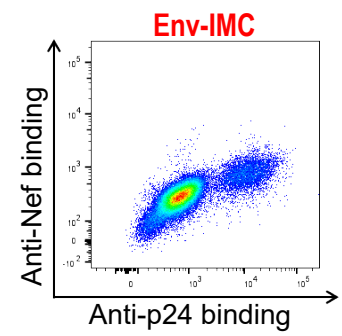

\section{Env-IMC-LucR.T2A}

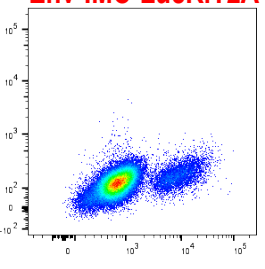

C

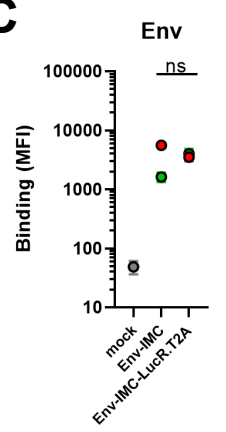

$\mathbf{F}$
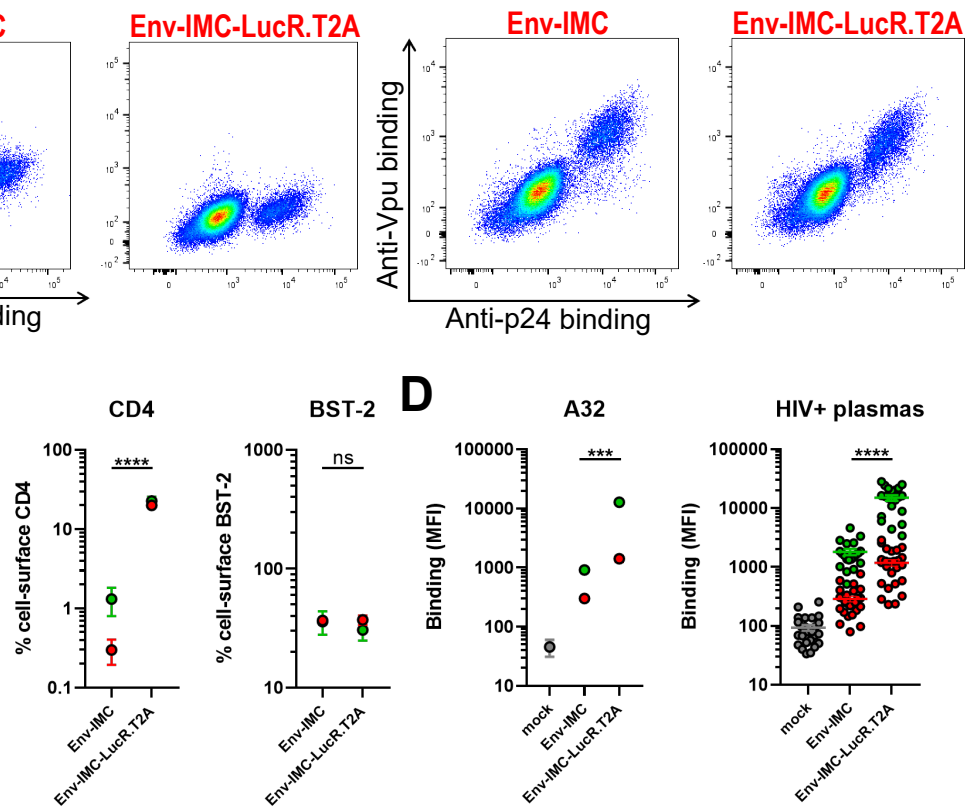

D
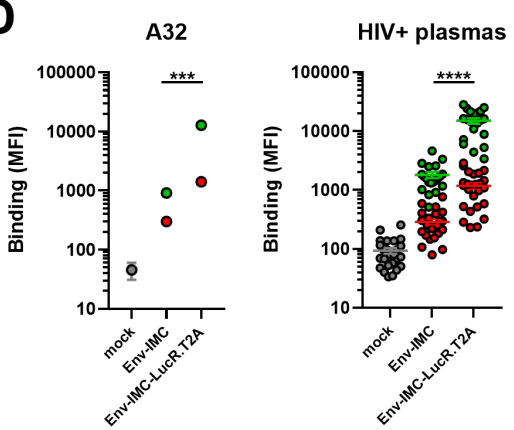

E
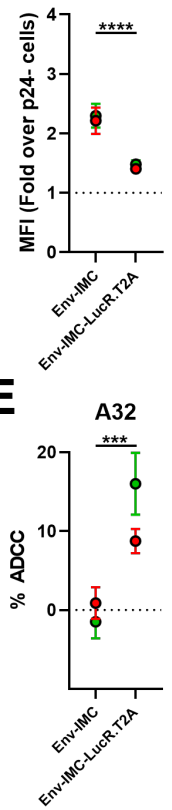

G

\section{Type}

- cellular factors

- immunological factors

- virological factors

Vpu

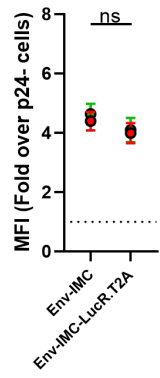

HIV+ plasmas

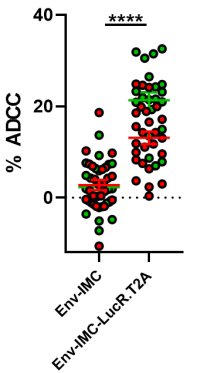

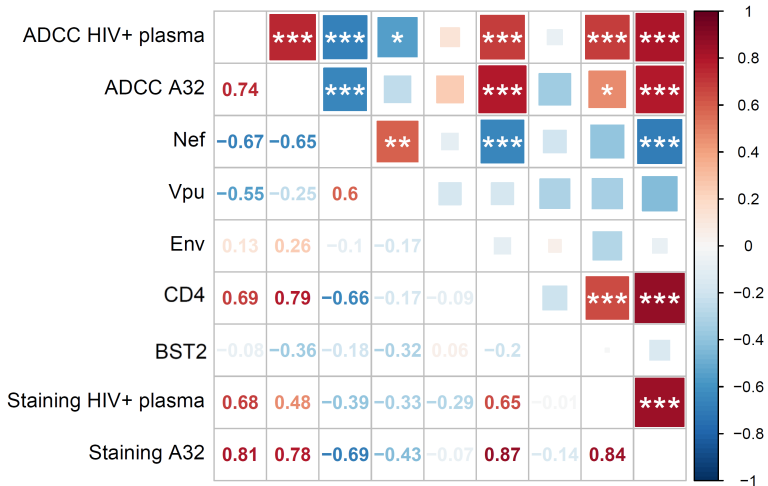
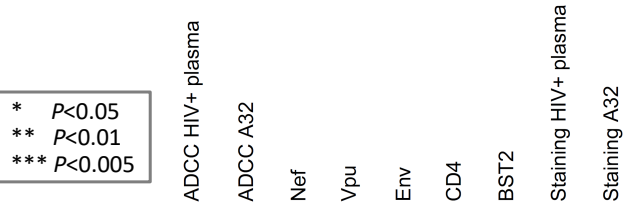
$-1$

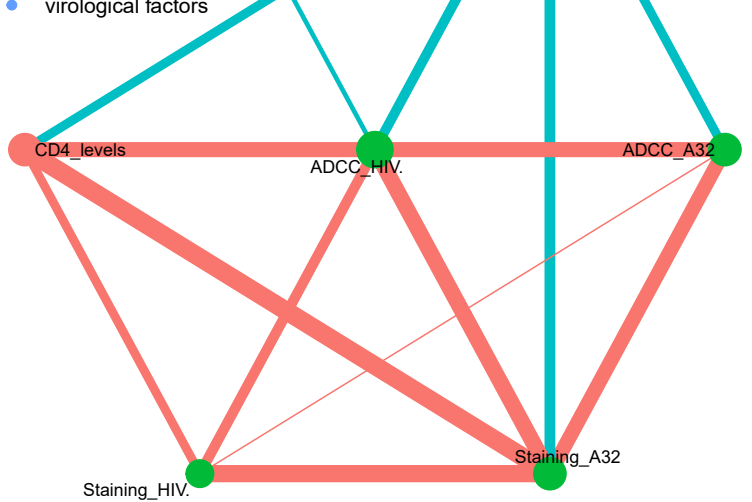


BST-2

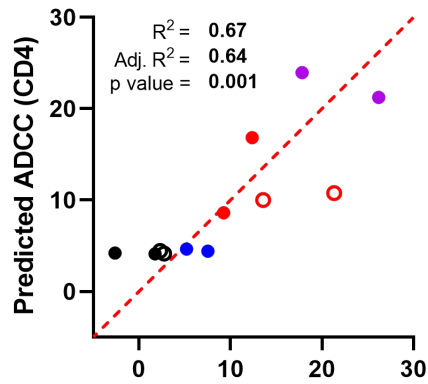

Actual ADCC (HIV+ plasma)

\section{Nef}

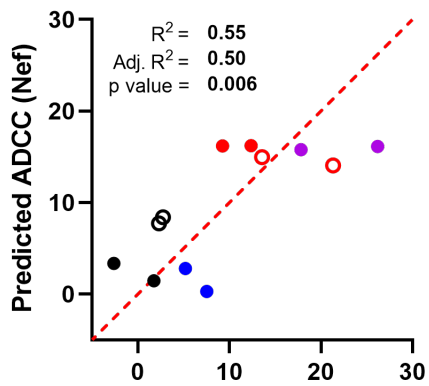

Actual ADCC (HIV+ plasma)

Nef/Vpu

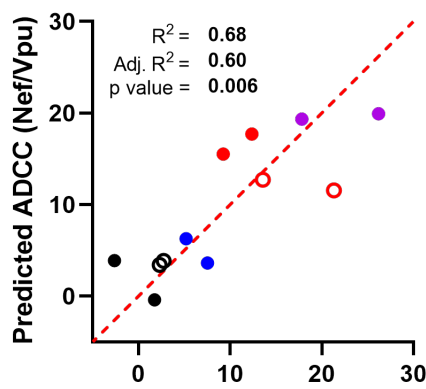

Actual ADCC (HIV+ plasma)

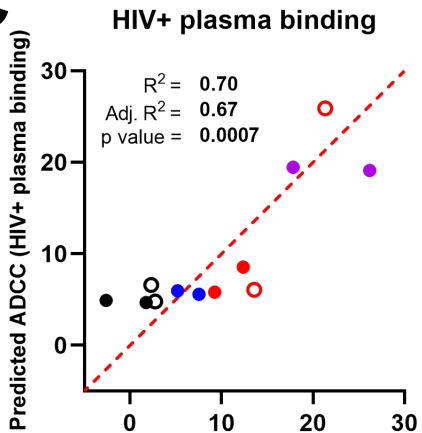

Actual ADCC (HIV+ plasma)

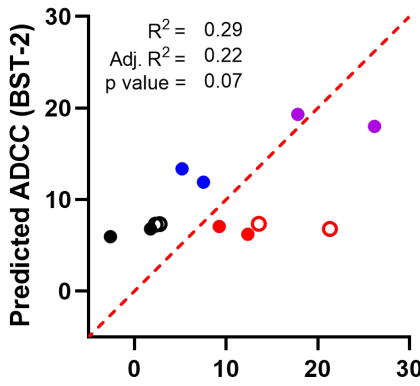

Actual ADCC (HIV+ plasma)

Vpu

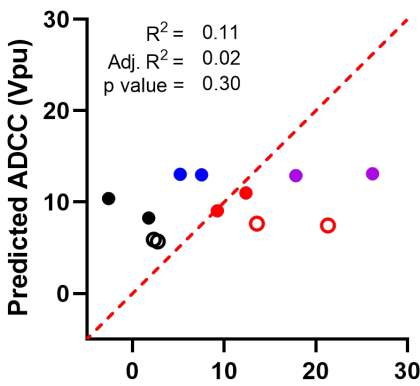

Actual ADCC (HIV+ plasma)

Nef/Env

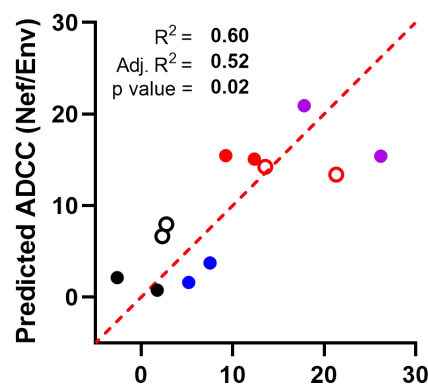

Actual ADCC (HIV+ plasma)

A32 binding

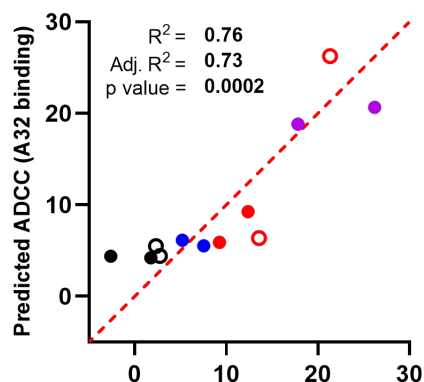

Actual ADCC (HIV+ plasma)
CD4/BST-2

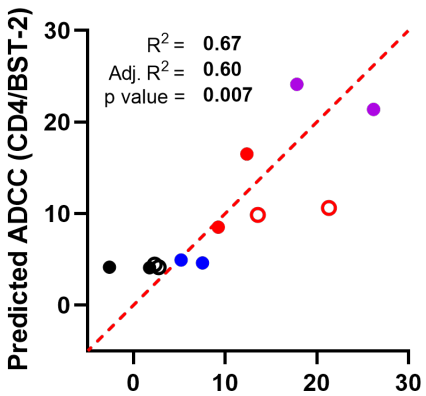

Actual ADCC (HIV+ plasma)

Env

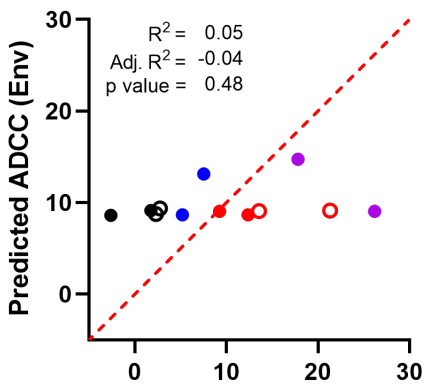

Actual ADCC (HIV+ plasma)

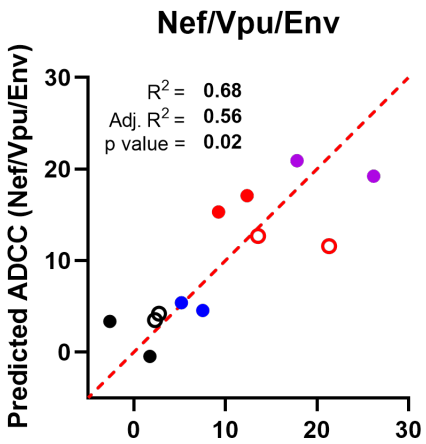

Actual ADCC (HIV+ plasma)

ADCC A32

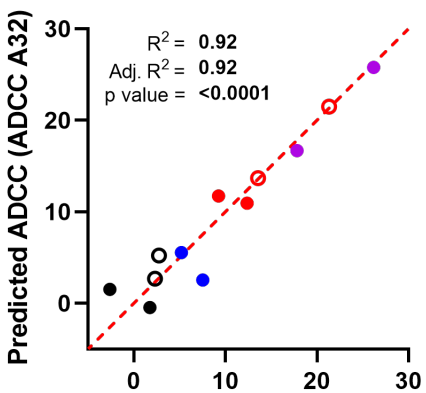

Actual ADCC (HIV+ plasma) 